\title{
Formy osuwiskowe w Górach Kamiennych (Sudety Środkowe) - kryteria identyfikacji i oceny zagrożeń
}

\author{
Landslide geomorphology of the Kamienne Mountains (Middle Sudetes) - criteria of \\ identification and hazard assessment
}

\author{
Piotr Migoń1, Andrzej Kacprzak², Ireneusz Malik³, Marek Kasprzak' \\ ${ }^{I}$ Instytut Geografii i Rozwoju Regionalnego,Uniwersytet Wrocławski,Wrocław,piotr.migon@uni.wroc.pl \\ ${ }^{2}$ Instytut Geografii i Gospodarki Przestrzennej, Uniwersytet Jagielloński, Kraków \\ ${ }^{3}$ Wydział Nauk o Ziemi, Uniwersytet Śląski, Sosnowiec
}

\begin{abstract}
Zarys treści: W Górach Kamiennych (Sudety Środkowe) powszechnie występują formy rzeźby związane z osuwiskami, które powstały w okresie przedhistorycznym. Zostały one rozpoznane na podstawie terenowego kartowania geomorfologicznego, wspomaganego interpretacją cyfrowego modelu wysokości zbudowanego z wysokorozdzielczych danych LiDAR, i dokumentują różne rodzaje przemieszczeń: translacyjne, rotacyjne, spływanie materiału, rozciąganie, a lokalnie również obrywy. Badania stopnia rozwoju gleb wskazują, że obok osuwisk starych, stabilnych w holocenie występują formy młode, które powstały lub były reaktywowane w holocenie. Na holoceńską aktywność wskazują także nieliczne daty radiowęglowe. Deformacje przyrostów rocznych drzew porastających osuwiska stwierdzone w trakcie badań dendrochronologicznych pozwalają wnioskować o utrzymującej się niestabilności niektórych form i powolnym ruchu. Ogólnie zagrożenia związane z osuwiskami w Górach Kamiennych w obecnych warunkach środowiskowych i przy obecnym stanie zagospodarowania można uznać za niewielkie, nieznana jest jednak możliwa reakcja osuwisk na postępujące zmiany klimatu i ewentualne zmiany użytkowania ziemi. Artykuł ma głównie charakter przeglądowy i zawiera podsumowanie wcześniej prowadzonych badań i ich opublikowanych rezultatów.
\end{abstract}

Słowa kluczowe: osuwiska, kartowanie geomorfologiczne, chronosekwencje gleb, dendrochronologia, zagrożenia geomorfologiczne, Sudety, LiDAR

\begin{abstract}
In the Kamienne Mountains (Middle Sudetes) landforms resulting from prehistoric landslides are common. They have been recognized through detailed field geomorphological mapping, aided by interpretation of high-resolution digital elevation models built from LiDAR data, and provide evidence of different types of movement, including translational and rotational slides, flowslides, lateral spreading, and rock fall. Soil research focused on soil development shows that ancient, stable landslide terrains coexist with much younger landslides, initiated or reactivated in the Holocene. Holocene activity is also suggested by sparse radiocarbon dates. Tree ring deformations revealed by dendrochronological research allow to infer persistent instability of certain landslides and their ongoing slow movement. Generally, hazards associated with landslides in the Kamienne Mts, given the current environmental conditions and land use, may be considered as low, but a possible reaction of landslide systems to climate change and any major land use changes is unknown. The paper is largely of review type and summarizes results obtained and published before.
\end{abstract}

Key words: landslides, geomorphological mapping, soil chronosequences, dendrochronology, geomorphological hazards, Sudetes, LiDAR

\section{Wstęp}

Ruchy masowe należą do tych naturalnych procesów geomorfologicznych, które oddziałują szczególnie destrukcyjnie na środowisko życia ludzi. Dlatego od dziesiątków lat pozostają $\mathrm{w}$ zakresie zainteresowań geomorfologii stosowanej (Cooke, Doornkamp 1990, Griffiths, Whitworth 2012). Zagrożenia i szkody materialne związane $\mathrm{z}$ ruchami masowymi są różne w zależności od typu ruchu. Do szczególnie niebezpiecznych i często tragicznych w skutkach należą obrywy, lawiny kamienne i spływy 
gruzowo-błotne - typowe dla środowiska gór wysokich oraz obszarów o wilgotnym klimacie, wysokich opadach i dużych nachyleniach stoków. W Polsce tego typu procesy występują bardzo rzadko i są ograniczone do najwyższych partii Tatr, Karkonoszy i Babiej Góry - obszarów generalnie niezamieszkanych, stąd zagrożenia z nimi związane są niewielkie, choć okazjonalnie spływy gruzowe mogą powodować uszkodzenia infrastruktury turystycznej i drogowej (Krzemień i in. 1995, Migoń, Parzóch 2008).

W przyrodniczych realiach Polski największe straty materialne są związane z procesami osuwiskowymi, rozumianymi jako przemieszczenia mas skalnych w warunkach stałego kontaktu z podłożem, wzdłuż wyraźnej powierzchni poślizgu (ścięcia). Obecność takiej powierzchni odróżnia osuwanie od powolnych przemieszczeń, takich jak soliflukcja i pełzanie gruntu, oraz znacznie szybszych spływów gruzowo-błotnych. Osuwiska mogą być różnego typu, obejmować skalne podłoże do głębokości kilkudziesięciu metrów bądź tylko pokrywę zwietrzelinową i przemieszczać się w różnym tempie, co znajduje odzwierciedlenie w różnych klasyfikacjach i typologiach osuwisk (Varnes 1978, Dikau i in. 1995, Margielewski 2004, Hungr i in. 2014). Regionem Polski najbardziej znanym z występowania osuwisk są Karpaty fliszowe - są one tam zarówno powszechne w sensie przestrzennym, jak i często inicjowane bądź reaktywowane (Rączkowski, Mrozek 2002, Margielewski i in. 2008). Na tle Karpat Sudety są zwykle postrzegane jako obszar wolny od zagrożeń procesami osuwiskowymi, a historyczne osuwiska były faktycznie bardzo rzadkie i generalnie niezbyt dużych rozmiarów (Pulinowa 1972, Migoń 2008, Parzóch, Migoń 2010). Prowadzone w ostatnich latach badania ujawniły jednak obecność na zalesionych stokach sudeckich, w szczególności w Górach Kamiennych w Sudetach Środkowych, licznych form osuwiskowych, o których brak było wzmianek w źródłach historycznych. W konsekwencji niejasny pozostawał ich wiek i aktualny status morfodynamiczny (stopień aktywności). W niniejszym artykule zostaną podsumowane najważniejsze wyniki tych badań, a formy osuwiskowe będą rozpatrywane z punktu widzenia zagrożeń i ryzyka dla elementów infrastruktury. Artykuł ma zatem charakter przeglądowy i stanowi syntezę wcześniejszych cząstkowych opracowań, cytowanych w dalszej części pracy, dostosowaną do potrzeb geomorfologii aplikacyjnej.

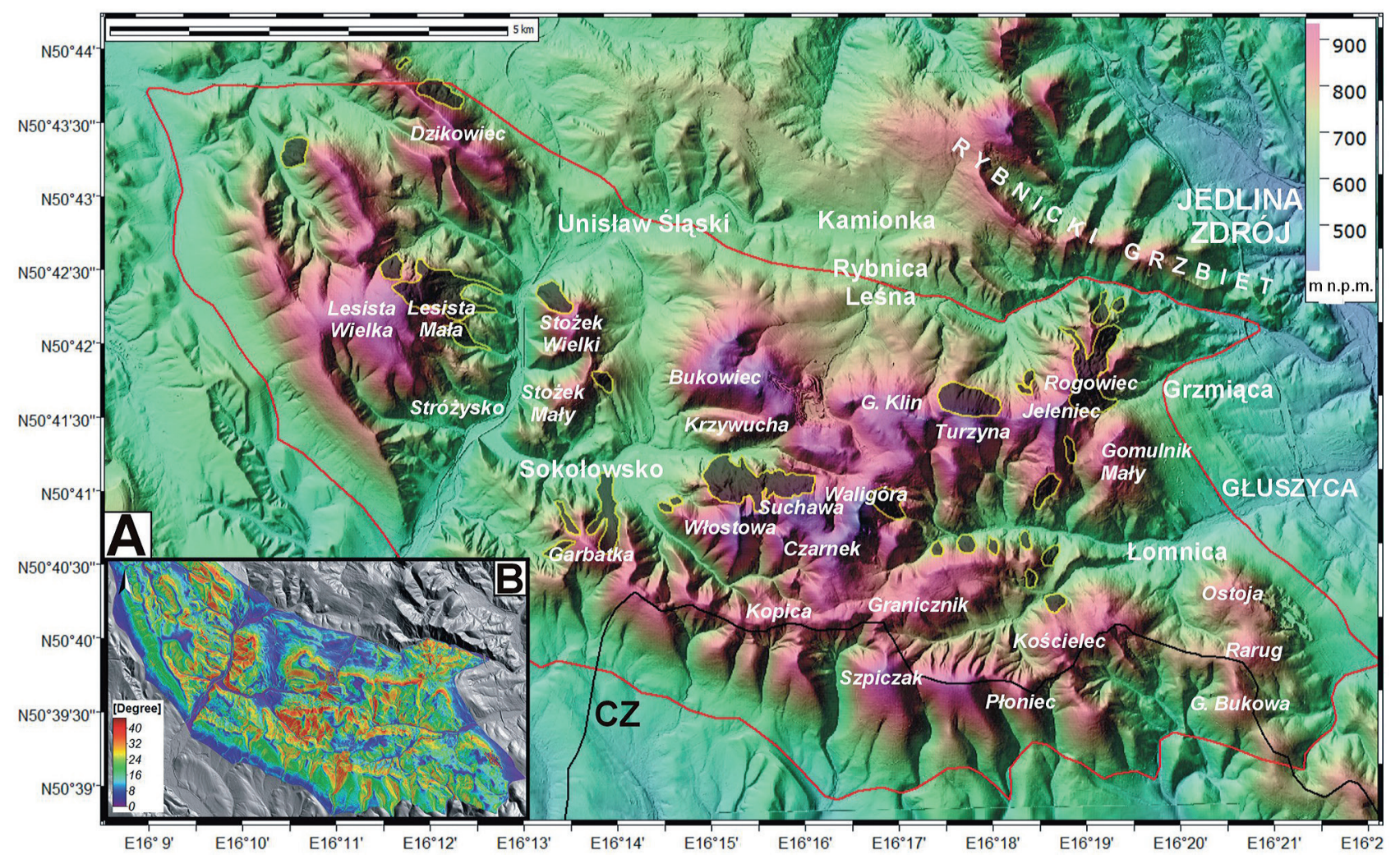

Ryc. 1. Obszar badań

A - cieniowany model rzeźby na podstawie danych LiDAR, zaznaczono lokalizację (obrys) obszarów osuwiskowych (za: Migoń i in. 2014a), ciągła czerwona linia wyznacza obszar, dla którego została obliczona frekwencja występowania poszczególnych klas nachyleń terenu (tab. 1), B - mapa nachyleń dla zachodniej części Gór Suchych, Masywu Dzikowca i Lesistej Wielkiej. CZ - Republika Czeska

Fig. 1. Area of research

A - hillshade model of relief built from LiDAR data, extent of landslide-affected slopes indicated after Migoń i in. (2014a), solid red line shows the boundary of an area for which the frequency of slope inclination classes has been determined (Table 1), B - slope angle map for the western part of the Suche Mountains and Dzikowiec and Lesista Wielka Massif. CZ - Czech Republic 


\section{Obszar badań}

\section{Położenie i główne cechy rzeźby}

Góry Kamienne wchodzą w skład Sudetów Środkowych i są długim, krętym pasmem (blisko $50 \mathrm{~km}$ ), składającym się z kilku części, którym nadano odrębne nazwy. Ich najbardziej zachodnim fragmentem są Góry Krucze o rozciągłości południkowej, z najwyższym szczytem Szeroką (843 m). Tworzą one wyraźny wał pomiędzy Lubawką i Kamienną Górą, opadający stromo ku zachodowi, w stronę obniżenia Bramy Lubawskiej. Przełom rzeki Zadrnej oddziela Góry Krucze od krótkiego i niskiego pasma Czarnego Lasu z najwyższą Czubą (660 m), natomiast dalej ku wschodowi wznosi się rozległy Masyw Dzikowca i Lesistej Wielkiej $(851 \mathrm{~m})$ o nieregularnym układzie grzbietów, kopuł i głębokich dolin (ryc. 1A). Przełomowa dolina Ścinawki stanowi granicę z najbardziej wschodnią i równocześnie największą powierzchniowo częścią Gór Kamiennych - Górami Suchymi, które ciągną się aż po dolinę Włodzicy na południe od Nowej Rudy. Są one równocześnie najwyższe w całym paśmie, z Waligórą (936 m) i kilkoma innymi szczytami przekraczającymi 900 m n.p.m. Składają się z dwóch części o odmiennym układzie linii grzbietowo-dolinnych. Część zachodnia cechuje się skomplikowanym układem wododziałów i znacznym rozczłonkowaniem, podczas gdy część wschodnia to praktycznie jeden grzbiet, wyraźnie niższy od wzniesień części zachodniej. Przez Góry Krucze i Góry Suche przebiega granica państwowa polsko-czeska, a fragmenty Gór Kamiennych po stronie czeskiej noszą odpowiednio nazwy Vraní hory (Vítek 1999) i Javoří hory (Smolová 2002).

Na tle całych Sudetów wysokości szczytów Gór Kamiennych są przeciętne, natomiast wyróżniają się one znacznymi wysokościami względnymi i nachyleniami

Tabela 1. Udział powierzchni stokowych o różnym nachyleniu w zachodniej części Gór Suchych i w Masywie Dzikowca i Lesistej Wielkiej (w granicach zaznaczonych na ryc. 1)

Table 1. The occurrence of slope surfaces of variable steepness in the western part of the Suche Mountains and in the Dzikowiec and Lesista Wielka Massif (within boundaries indicated on Fig. 1).

\begin{tabular}{ccc}
\hline $\begin{array}{c}\text { Nachylenie stoku }\left(^{\circ}\right) \\
\text { Slope angle }\left(^{\circ}\right)\end{array}$ & $\begin{array}{c}\text { Powierzchnia } \\
\left(\mathrm{km}^{2}\right) \\
\text { Surface area } \\
\left(\mathrm{km}^{2}\right)\end{array}$ & $\begin{array}{c}\text { Udział w całkowitej } \\
\text { powierzchni }(\%)\end{array}$ \\
$\begin{array}{c}\text { Percentage of the total } \\
\text { area }\end{array}$ \\
\hline $0-5$ & 6,50 & 8,3 \\
$5-10$ & 15,12 & 19,3 \\
$10-15$ & 14,42 & 18,4 \\
$15-20$ & 13,63 & 17,4 \\
$20-25$ & 11,41 & 14,6 \\
$25-30$ & 9,21 & 11,8 \\
$30-35$ & 6,05 & 7,7 \\
$35-40$ & 1,52 & 1,9 \\
$40-45$ & 0,22 & 0,3 \\
$45-50$ & 0,06 & 0,1 \\
$>50$ & 0,07 & 0,1 \\
Razem & 78,22 & 100,0 \\
\hline
\end{tabular}

stoków (Placek 2011). Energia rzeźby powszechnie przekracza wartość $200 \mathrm{~m}$ w polu $1 \mathrm{~km}^{2}$, a w wielu miejscach wynosi ponad $300 \mathrm{~m}$ na $1 \mathrm{~km}^{2}$. Nachylenia stoków powyżej $25^{\circ}$ są powszechne (ponad $20 \%$ obszaru), ale i wartości powyżej $40^{\circ}$ nie należą do rzadkości, szczególnie w zachodniej części Gór Suchych (tab. 1, ryc. 1B). Różnice wysokości między kulminacjami Gór Kamiennych a sąsiednimi obniżeniami dochodzą do $350-450 \mathrm{~m}$.

\section{Budowa geologiczna}

Zarówno regionalne, jak i lokalne cechy rzeźby Gór Kamiennych pozostają $\mathrm{w}$ ścisłym związku $\mathrm{z}$ budową geologiczną. Przebieg pasma naśladuje przebieg wychodni skał wulkanicznych i subwulkanicznych wieku głównie permskiego, podrzędnie późnokarbońskiego, powstałych w etapie postorogenicznego wulkanizmu w obrębie niecki śródsudeckiej w schyłkowym okresie ruchów waryscyjskich (Nowakowski 1968, Awdankiewicz 1999). Aktywność wulkaniczna była długotrwała i wielofazowa, stąd bogactwo typów skał wulkanicznych. Najbardziej rozpowszechnione są riolity (porfiry wg dawnego nazewnictwa), ponadto występują trachyandezyty (dawniej określane jako melafiry), trachybazalty i tufy riolitowe w różnych odmianach, w tym ignimbryty (Awdankiewicz 1999). Subwulkaniczny charakter mają przede wszystkim trachyandezyty (ale nie wszystkie), tworzące pokładowe intruzje - sille - w obrębie skał osadowych. Wulkanizm miał miejsce $\mathrm{w}$ obrębie rozległego obniżenia wypełnianego w późnym karbonie i wczesnym permie osadami lądowymi, zróżnicowanymi litologicznie i facjalnie. Reprezentują one pełne spektrum skał klastycznych, od gruboziarnistych zlepieńców przez piaskowce, mułowce, po iłowce i łupki ilaste (Grocholski 1973, Bossowski, Ihnatowicz 1994). Lądolód skandynawski w plejstocenie nie dotarł do wschodniej części Gór Kamiennych: Gór Suchych i Masywu Lesistej Wielkiej, stąd brak w ich obrębie utworów pochodzenia glacjalnego. W jego zasięgu znalazła się natomiast północna część Gór Kruczych, jednak zapewne wystawała ona ponad powierzchnię lodu (Synowiec, Traczyk 2004).

\section{Rozwój rzeźby}

W zakresie geomorfologii do końca XX w. Góry Kamienne należały do zaniedbanych pod względem badawczym części Sudetów. Szczepankiewicz (1954) próbował interpretować ich rzeźbę w kategoriach rozwoju cyklicznego i tworzenia poziomów zrównań, ale koncentrował się na położonych bardziej na północ okolicach Wałbrzycha. W rzeczywistości rzeźba Gór Kamiennych jest przede wszystkim rzeźbą strukturalną (Placek 2011, Migoń, Placek 2014). Znaczne różnice wysokości i nachylenia stoków w Górach Kamiennych wynikają głównie z sąsiedztwa skał wulkanicznych i osadowych, cechujących się zdecydowanie odmienną wytrzymałością i odpornością na niszczenie przez procesy denudacyjne. Skały wulkaniczne zostały wypreparowane spośród miękkich 


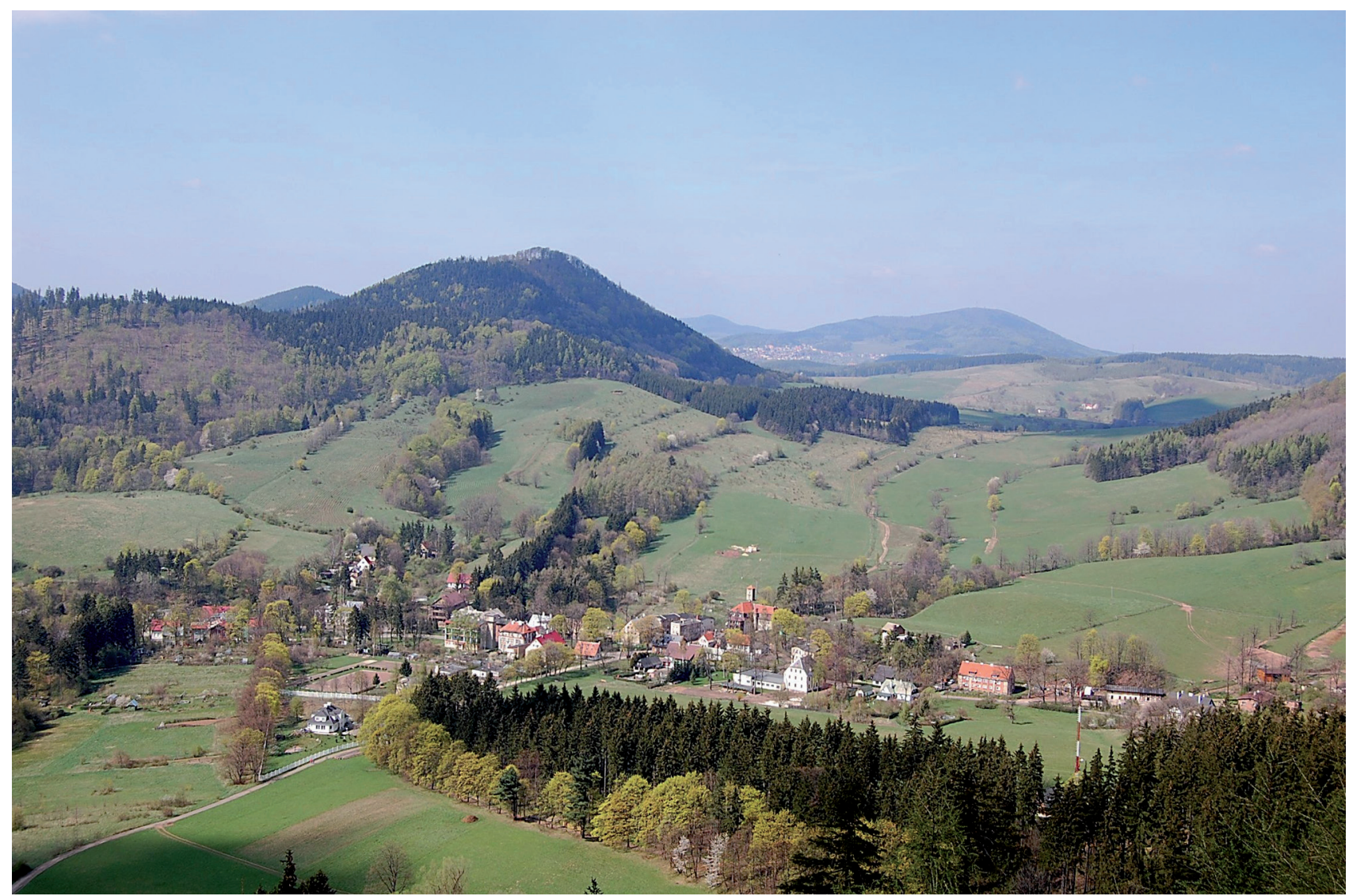

Ryc. 2. Kontrasty rzeźby w Górach Suchych. Kotlina Sokołowska (na pierwszym planie) jest wypreparowana w skałach osadowych, za nią wznosi się trachyandezytowy masyw Stożka Wielkiego, a różnica wysokości sięga $400 \mathrm{~m}$. Zdjęcie wykonane ze stoków Włostowej zbudowanej z riolitów

Fig. 2. Relief contrasts in the Suche Mountains. The Sokołowsko Basin (foreground) is excavated in sedimentary rocks and is overlooked by the trachyandesite massif of Mt Stożek Wielki; elevation difference reaches $400 \mathrm{~m}$. Photograph taken from the slopes of Mt Włostowa, built of ryolites

skał osadowych, stąd zbudowane z nich grzbiety, kopuly i stożki mają naturę twardzielców. Skały osadowe występują w obrębie kotlinowatych obniżeń (np. Kotlina Sokołowska), podłużnych dolin rzecznych oraz falistych równin sąsiadujących $\mathrm{z}$ grzbietami zbudowanymi ze skał wulkanicznych (ryc. 2). Pogląd o twardzielcowym charakterze pasma był już prezentowany $\mathrm{w}$ starszych opracowaniach (Walczak 1972), jednak jego empiryczne potwierdzenie $\mathrm{w}$ postaci pomiarów wytrzymałości skał przedstawiono dopiero niedawno (Synowiec, Migoń 2002, Placek 2011). Niewątpliwie istotne znaczenie morfogenetyczne miała erozja rzeczna, za sprawą której głębokie doliny powstały także w obrębie kompleksów skał wulkanicznych (ryc. 1). W plejstocenie wychodnie skalne były poddane intensywnemu wietrzeniu mechanicznemu, a na stokach tworzyły się pokrywy gruzowo-głazowe i gliniasto-gruzowe (Synowiec, Traczyk 2004), szybko przemieszczane grawitacyjnie w dół dzięki znacznym nachyleniom stoków. W holocenie, wskutek utrwalenia powierzchni stoku przez zbiorowiska leśne, pokrywy wietrzeniowe zaczęly się odnawiać (Migoń, Kacprzak 2014).

\section{Występowanie osuwisk i ich identyfikacja}

\section{Historia badań}

Obecność form rzeźby związanych z wielkoskalowymi ruchami masowymi w Masywie Dzikowca i Lesistej Wielkiej oraz w Górach Suchych została zauważona już przez geologów niemieckich wykonujących $\mathrm{w}$ początkach XX w. pierwsze szczegółowe mapy geologiczne regionu wałbrzyskiego w skali 1:25 000 (Berg i in. 1910, Dathe i in. 1910, Berg 1925, Dathe, Berg 1926). Miały one powstać wskutek nagłych, katastrofalnych ruchów masowych, które obejmowały nawet całe skaliste wzniesienia (niem. Rutschungen ganzer Felsklippen). Wskazywano m.in. na większe nachylenia partii czołowych płatów osuwiskowych w stosunku do przyległej powierzchni stokowej i poziomą lub nawet wstecznie pochyloną górną powierzchnię płatów oraz obecność zagłębień bezodpływowych, co odpowiada typowemu zespołowi form związanych z osuwiskami rotacyjnymi.

Problematyka osuwisk ponownie pojawiła się w literaturze na początku lat 70. XX w. w formie ogólnych opisów rzeźby związanej z ruchami masowymi na wschodnich stokach Lesistej Wielkiej (Grocholski 1972) i na wschodnich stokach Rogowca w północno-wschodniej 
części Gór Suchych, gdzie szczególne zainteresowanie wzbudziły długie strumienie blokowe w obrębie stoku osuwiskowego (Pulinowa, Mazur 1971, Pulinowa 1972). Osuwiska w rejonie Lesistej Wielkiej zostały także zaznaczone na arkuszu Mieroszów Szczegółowej Mapy Geologicznej Sudetów (SMGS) w skali 1:25 000 (Grocholski 1971), a kilka osuwisk w Górach Kruczych - na arkuszu Lubawka (Don i in. 1979). Jońca (1987) zamieścił szkic orograficzny centralnej części Gór Suchych, zaznaczając liczne nisze osuwiskowe, jednak bez dokładniejszego opisu form i osadów. Dla tego samego obszaru liczne płaty koluwiów osuwiskowych różnej wielkości zaznaczyli autorzy arkusza Jedlina Zdrój SMGS (Bossowski $\mathrm{i}$ in. 1994).

Dalsze badania geomorfologiczne wybranych osuwisk przeprowadził Synowiec (2003a, b, 2005), jednak tylko w niewielkiej części zostały one opublikowane. Łącznie potwierdził on istnienie 25 osuwisk, niektórych o złożonym charakterze, w tym 19 w Górach Suchych, 2 na Lesistej Wielkiej i 4 w Górach Kruczych, oceniając ich całkowitą powierzchnię na 132 ha (Synowiec 2003a). Najnowsze, kompleksowe badania przy wykorzystaniu klasycznych metod geomorfologicznych (kartowanie terenowe), pomiarów terenowych dynamiki pokryw gruzowych w obrębie nisz osuwiskowych, analiz geomorfometrycznych, metod geofizycznych, gleboznawczych i dendrochronologicznych znacząco wzbogaciły stan rozpoznania rzeźby osuwiskowej Gór Kamiennych, a kilka zespołów osuwisk doczekało się szczegółowych opracowań (Malik i in. 2009, Migoń 2010, Migoń i in., 2010, 2014b, Kasprzak, Traczyk 2012, Remisz, Bijak 2012, Kacprzak $i$ in. 2013, Wistuba $i$ in. 2013). Udostępnienie w 2013 r. wysokorozdzielczych danych o topografii terenu pochodzących $\mathrm{z}$ lotniczego skaningu laserowego (LiDAR) pozwoliło zbudować cyfrowy model wysokości o dokładności znacznie przewyższającej wszelkie istniejące materiały kartograficzne i w konsekwencji zweryfikować wcześniej przedstawiane zasięgi osuwisk. W trakcie analiz rzeźby wykorzystujących dane LiDAR ustalono łączną powierzchnię zajętą przez osuwiska w Masywie Dzikowca i Lesistej Wielkiej oraz w Górach Suchych na ponad 300 ha (Migoń i in. 2014a).

\section{Osuwiska na szczególowych mapach geologicznych}

Zarówno niemieckie szczegółowe mapy geologiczne z początków XX w. (Berg i in. 1910, Berg 1925), jak i polskie z końca XX w. (Grocholski 1971, Don i in. 1979, Bossowski i in. 1994) zawierają oznaczenia obszarów objętych przez osuwiska, aczkolwiek miejscami są widoczne rozbieżności między nimi w zakresie obecności osuwisk i ich zasięgu. Łączna powierzchnia zajęta przez płaty osuwiskowe na mapach niemieckich wynosi 76,5 ha, na mapach polskich (bez uwzględnienia Gór Kruczych) - 87,7 ha (Migoń $\mathrm{i}$ in. 2014a). Informacji o zastosowanych kryteriach identyfikacji osuwisk dostarczają opisy w objaśnieniach towarzyszących poszczególnym arkuszom (Dathe i in. 1910, Dathe, Berg 1926, Grocholski 1973, Bossowski i in. 1995).

Kartując osuwiska, autorzy niemieccy przyjęli głównie kryterium litologiczne, zaznaczając miejsca występowania zwartych mas skał wulkanicznych w pozycji allochtonicznej, na skałach osadowych budujących dolne części stoków. W tekście objaśnień została dodatkowo odnotowana obecność luźnych pokryw blokowych skał wulkanicznych na podłożu ze skał osadowych, na przykład pod Rogowcem, ale zgodnie z przyjętą zasadą zaznaczania tylko zwartych pakietów, nie znalazło to odzwierciedlenia na mapie. Nie ulega jednak wątpliwości, że ważnym kryterium pomocniczym w identyfikacji osuwisk była obserwacja kształtu stoku, a schodowy (tarasowy) profil był traktowany jako wskaźnik obecności osuniętych mas skalno-zwietrzelinowych.

Polskie mapy geologiczne w różny sposób przedstawiają elementy rzeźby osuwiskowej. Na mapach z lat 70 . XX w. (arkusze Lubawka i Mieroszów) posłużono się znakiem graficznym osuwiska, obrysowując konturem cały obszar objęty przez ruchy masowe typu osuwiskowego. Takie podejście wskazuje, że analiza rzeźby stoku była podstawą wydzielenia, a na zastosowanie sygnatury osuwiska decydowano się wówczas, gdy formy rzeźby (nisze, rynny, nabrzmienia w dolnej części stoku) były wyraźne. W przeciwnym przypadku oznaczano czwartorzędowe rumosze skalne, choć miejscami nie wykluczano ich związku z przemieszczeniami grawitacyjnymi, o czym świadczy następujące zdanie: „W morfologii zaznaczają się [one] jako lekkie nabrzmienia u podnóży stromo nachylonych stoków. Dodatkowym wskaźnikiem są źródła i wycieki wodne występujące wzdłuż dolnej, zatokowo powyginanej krawędzi”, a dalej: „Osuwiska. Utwory te (...) nie różnią się od opisanych poprzednio [rumoszów skalnych]. Są jednak prawdopodobnie nieco młodsze i dzięki temu lepiej zaznaczone w morfologii terenu" (Grocholski 1973, s. 58). Inaczej oznaczono osuwiska na wydanym w latach 90. XX w. arkuszu Jedlina Zdrój. Powszechnie stosowanym wydzieleniem są plejstoceńskie rumosze skalne i iły zwietrzelinowe, na które w różnych miejscach nałożono sygnatury osuwisk i gołoborzy. Nie występują one poza płatami wspomnianych rumoszów i iłów. Na Turzynie zaznaczono ponadto linijną krawędź obrywu, a znajdujące się poniżej niej trachybazalty jako osunięte en bloc.

Analiza map geologicznych i opisów objaśniających $\mathrm{w}$ połączeniu z obecnym rozpoznaniem terenowym prowadzi do dwóch wniosków. Po pierwsze, ważną rolę w identyfikacji osuwisk odegrała interpretacja rzeźby terenu, choć niedostateczna dokładność map topograficznych i obecność zwartych zbiorowisk leśnych na pewno nie ułatwiały precyzyjnej delimitacji granic osuwisk. Porównanie modelu wysokości $\mathrm{z}$ danych LiDAR z mapą geologiczną SMGS, arkusz Mieroszów wykazało, że rzeczywista powierzchnia osuwisk jest dużo większa niż wskazuje mapa (Migoń i in. 2014a). Po drugie, na większości map oznaczenia osuwisk są podporządkowane wydzieleniom utworów stokowych (sygnatury osuwisk są na 
nie nałożone), co oznacza, że kartograficznie wydzielano zasadniczo strefy depozycji w obrębie osuwisk, a nie osuwiska jako całość. Stwierdzono także błędne oznaczenia koluwiów osuwiskowych w niektórych dolinach 1 . rzędu jako holoceńskich utworów aluwialnych (Kasprzak i in. 2014, Migoń i in. 2014a).

\section{Geomorfologiczne kryteria rozpoznawania rzeźby osuwiskowej w terenie}

W rozpoznawaniu elementów rzeźby osuwiskowej i wyznaczaniu granic osuwisk, szczególnie na obszarach zalesionych, przez wiele lat kluczowe znaczenie miała terenowa analiza układu form rzeźby i identyfikacja form uważanych za wskaźnikowe dla ruchów osuwiskowych w ogólności, ewentualnie ich poszczególnych rodzajów. Klasyczną pracą w tym zakresie jest „Landslide Recognition” (Dikau i in. 1995), w której omówiono główne rodzaje wielkoskalowych ruchów masowych - obrywy, przewracanie, osuwanie translacyjne, osuwanie rotacyjne, spływy, osuwiska o budowie złożonej i ich wyraz morfologiczny. W Polsce do tego podziału nawiązują wytyczne do opracowania „Mapy osuwisk i terenów zagrożonych ruchami masowymi” w ramach Systemu Osłony Przeciwosuwiskowej SOPO (Grabowski i in. 2008). Analiza form nie zawsze pozwala na jednoznaczną identyfikację typu osuwiska, bywa więc uzupełniana analizą morfometryczną (np. Crozier 1973, Dewitte, Demoulin 2005, Hattanji, Moriwaki 2009), a przede wszystkim badaniami strukturalnymi w odsłoniętych pakietach skalnych, co m.in. pozwala na rozróżnienie osuwisk rotacyjnych i translacyjnych (Margielewski 2004, 2009), czy szerzej - wskazanie strukturalnych uwarunkowań niestabilności stoków (Bober 1984).

W trakcie badań terenowych w Górach Kamiennych szczególną uwagę zwrócono na cztery elementy rzeźby jako diagnostyczne dla przemieszczeń osuwiskowych różnego typu:

- stromą skarpę w górnej części stoku, wyznaczającą położenie skarpy głównej - zamknięcia strefy oderwania (tzw. niszy osuwiskowej);

- spłaszczenia, wydłużone formy wklęsłe i zagłębienia w obrębie stoku, zwykle wskazujące na rotacyjny (ścięciowy) charakter ruchu;

- nieregularną, falisto-pagórkowatą rzeźbę dolnej części stoku, odpowiadającą strefie akumulacji koluwiów osuwiskowych;

- płaskie i wypukłe w profilu poprzecznym dna dolin 1. rzędu, pozbawionych stałego odwodnienia, zatem trudne do wythumaczenia procesami transportu i depozycji fluwialnej.

Skarpa glówna. Stoki Gór Kamiennych ogólnie cechują się dużym nachyleniem (ryc. 1B), ale w profilu podłużnym zmienia się ono nieznacznie i przy jednolitej budowie geologicznej profile podłużne stoku są ogólnie prostoliniowe. Grzbiety są na wielu odcinkach ostre. W przypadku wzniesień o kształcie kopuły brak na ogół wyraźnego załomu między stromym stokiem a spłaszczo- ną wierzchowiną. Częste występowanie skał wulkanicznych w górnej części stoku i osadowych poniżej skutkuje zmianą nachylenia i występowaniem wyraźnego załomu wklęsłego.

Z tymi ogólnymi cechami powierzchni stokowej kontrastuje obecność poprzecznych skarp o przebiegu linijnym lub łukowatym, zaburzających wyrównany profil podłużny stoku. W ich obrębie nachylenie rośnie nawet do $40-50^{\circ}$, mogą się też pojawiać wychodnie skał wulkanicznego podłoża $\mathrm{w}$ formie ścian lub pojedynczych ambon i baszt skalnych. Wysokość skarp jest zróżnicowana, od kilku metrów do ponad $25 \mathrm{~m}$, przy czym ściany skalne mogą się wznosić do 15-20 m (ryc. 3A). Długość skarp jest także różna: od kilkudziesięciu do kilkuset metrów (maksymalnie $700 \mathrm{~m}$ pod grzbietem Turzyny). Poniżej stromego odcinka stoku zwykle rozciąga się usypisko zbudowane $\mathrm{z}$ ostrokrawędzistych głazów i gruzu skalnego, $\mathrm{z}$ reguły porośnięte, niemniej w wielu miejscach niestabilne. Lokalnie przybiera ono postać wyraźnych stożków usypiskowych pozbawionych roślinności. Taka sytuacja ma miejsce na przykład pod Suchawą (ryc. 3B).

Spłaszczenia i obniżenia śródstokowe. Poniżej linijnych lub łukowatych skarp w górnej części stoku stwierdzono w wielu miejscach występowanie dalszych elementów rzeźby zaburzających prostoliniowy lub wklęsły profil powierzchni stokowej. Bezpośrednio poniżej ścian skalnych pojawiają się równoległe do nich rowy (np. pod Włostową) lub pochylone przeciwstawnie do ogólnego nachylenia stoku półki - spłaszczenia (np. pod Turzyną, ryc. 3C). Ich długość wynosi od kilkudziesięciu do ponad $400 \mathrm{~m}$. Pod Suchawą wstecznie przechylone spłaszczenia występują $\mathrm{w}$ powtarzalnym układzie i można $\mathrm{w}$ tym miejscu wyróżnić przynajmniej cztery takie elementy. Szczególną rolę wskaźnikową w identyfikacji przemieszczeń osuwiskowych odgrywają zagłębienia bezodpływowe, aczkolwiek takich form jest w Górach Kamiennych tylko kilka. Mają one zwykle nieregularny zarys i występują w obrębie nieregularnej, pagórkowatej powierzchni stokowej (np. na wschodnich stokach Rogowca). Pod Jeleńcem Małym zagłębienie bezodpływowe znajduje się na zapleczu lokalnej kulminacji w obrębie stoku, utworzonej przez zwarty pakiet skalny zbudowany $\mathrm{z}$ trachyandezytów (ryc. 3D). Zagłębienia są wypełnione namytym materiałem mineralnym i organicznym, a niektóre z nich są zajęte przez płytkie zbiorniki wód stojących.

Powierzchnie faliste i pagórkowate. Kolejnym charakterystycznym elementem rzeźby stoków Gór Kamiennych są nieregularne zespoły pagórków, nabrzmień i bruzd pojawiające się w ich dolnych częściach. Różnice wysokości w obrębie takich powierzchni sięgają $10 \mathrm{~m}$. Największy obszar tego typu znajduje się po południowej stronie doliny potoku Sokołowiec, poniżej pasa riolitowych wzniesień Suchawa-Kostrzyna-Włostowa, zajmując obszar o przybliżonych wymiarach $900 \times 300 \mathrm{~m}$. W niektórych miejscach strefa pagórkowatej rzeźby kończy się wyraźnym czołem, na przykład pod Włostową, gdzie wznosi się ono bezpośrednio powyżej płaskiego dna doliny na wysokość około $6 \mathrm{~m}$ (ryc. 3E). Nieregular- 

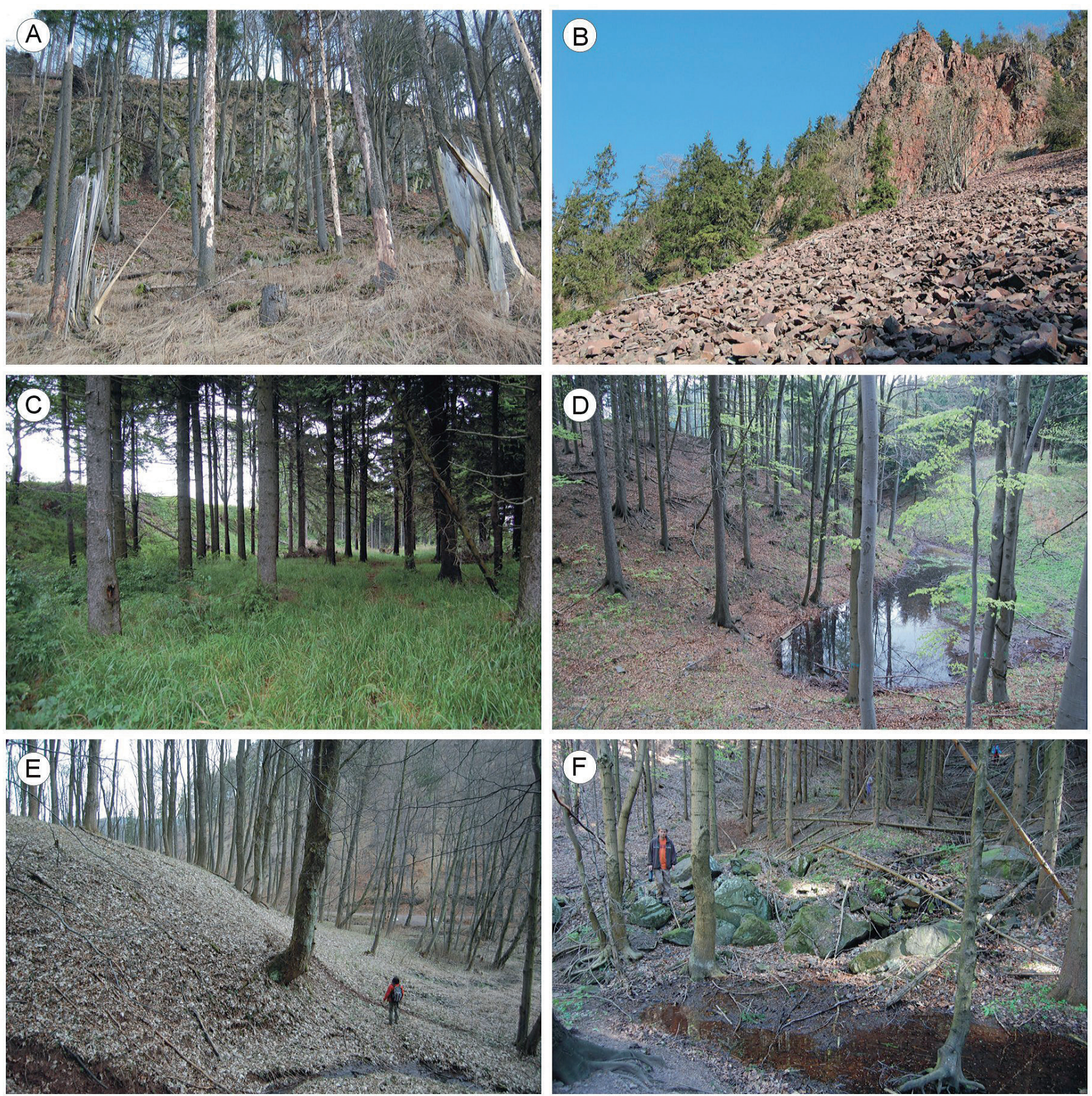

Ryc. 3. Przykłady elementów rzeźby osuwiskowej w Górach Suchych

A - skalista skarpa główna osuwiska na północnych stokach Stożka Wielkiego, B - usypiska riolitowe pod skarpą główną osuwiska pod Suchawą, C - nieznacznie obniżony płat osuwiskowy pod Turzyną, z tyłu skarpa główna o wysokości $10 \mathrm{~m}, \mathrm{D}$ - zagłębienie bezodpływowe z jeziorkiem na osuwisku pod Jeleńcem Małym, E - część czołowa obszaru osuwiskowego pod Włostową, bezpośrednio powyżej dna doliny Sokołowca, F - głazy trachyandezytu w obrębie jęzora osuwiskowego wypełniające dolinkę pod Rogowcem

Fig. 3. Examples of landslide morphology in the Suche Mountains

A - rocky head scarp of a landslide at Mt Stożek Wielki, B - ryolite scree below the head scarp at Mt Suchawa, C - displaced landslide block below Mt Turzyna, with $10 \mathrm{~m}$ high head scarp in the background, D - closed depression with a pond on the Jeleniec Mały landslide, E - frontal part of landslide depositional area below Mt Włostowa, immediately above the valley floor of Sokołowiec creek, $\mathrm{F}$ - trachyandesite boulders within a landslide tongue below Mt Rogowiec

ną rzeźbę powierzchni terenu stwierdzono także w pozycji wododziałowej, pomiędzy stożkowymi wzniesieniami Rogowca i Jeleńca Małego, gdzie dodatkowo urozmaica ją obecność rozległego blokowiska trachyandezytowego.

Plaskie i wypukłe dna dolin. Z typowymi dla Gór Kamiennych głębokimi V-kształtnymi dolinami wciosowymi, o stromych zboczach i wąskim dnie, kontrastują dolinki o płaskim bądź nawet wypukłym profilu poprzecznym dna. Stwierdzono je między innymi w masywie Lesistej Wielkiej (Migoń i in. 2010), na południe od Sokołowska pod Garbatką (Kasprzak i in. 2014, Migoń i in. 2014b) i w masywie Rogowca. Szerokość dna waha się od 15-20 m do ponad $100 \mathrm{~m}$, a wyniesienie centralnej części wypukłości w stosunku do obniżonej części brzeżnej 
może sięgać 6-8 m. Obecność allochtonicznych głazów skał wulkanicznych w dnach dolin, niekiedy w znacznych ilościach (np. pod Garbatką i Rogowcem - ryc. 3F), i wyniki badań elektrooporowych (Migoń i in. 2010, Kasprzak i in. 2014) wskazują, że płasko-wypukłe dno jest efektem akumulacji materiału pochodzącego z górnych odcinków dolin. Morfologia części dystalnych wypełnien dolin jest zróżnicowana. W niektórych przypadkach materiał wypełniający doliny tworzy w swej brzeżnej części strome czoło o wysokości kilku metrów, w innych trudno jednoznacznie wyznaczyć granicę występowania utworów genetycznie związanych $\mathrm{z}$ osuwaniem, a przejście $\mathrm{w}$ aluwialne dno niższego odcinka doliny jest nieostre. $Z$ reguły trudno także wskazać, gdzie rozpoczyna się strefa wypełnienia doliny materiałem stokowym, stąd długość opisywanych odcinków przekształconych przez ruchy masowe można jedynie oszacować. Najkrótsze mają poniżej 100 m, najdłuższe (pod Garbatką - Migoń i in. 2014b) dochodzą do $900 \mathrm{~m}$.

Kolejnym elementem rzeźby, genetycznie powiązanym $\mathrm{z}$ ruchami masowymi, są szczeliny $\mathrm{z}$ rozciągania. W Górach Kamiennych znane jest jedno miejsce ich występowania - pod kulminacją Lesistej Wielkiej, zbudowaną z grubego pakietu tufów riolitowych spoczywających na wkładce skał osadowych. Były one opisywane w regionalnej literaturze krajoznawczej jako Szczeliny Wiatrowe, która to nazwa podkreślała szczególne cechy lokalnej cyrkulacji powietrza krążącego w głębokim systemie rozpadlin (Dudziak 1984). W okresie zimowym wydostające się ze szczelin powietrze jest cieplejsze od otoczenia, co często skutkuje zanikiem pokrywy śnieżnej wokół szczelin. Szczeliny mają do $20 \mathrm{~m}$ długości i $4 \mathrm{~m}$ głębokości. Badania metodą tomografii elektrooporowej wykazały, że system rozluźnień ma większy zasięg przestrzenny i sięga do 20-30 m w głąb masywu skalnego (Migoń i in. 2010). Szczeliny znajdują się w sąsiedztwie wyraźnego zespołu skarp i półek typowych dla wielokrotnego osuwiska rotacyjnego i mają podobną orientację jak skarpy $\left(130^{\circ}\right)$. Obecność Szczelin Wiatrowych jest interpretowana jako morfologiczny wyraz inicjalnej fazy głęboko zakorzenionego ruchu osuwiskowego i tendencji do propagacji przemieszczeń grawitacyjnych w kierunku północno-zachodnim (Migoń i in. 2010).

\section{Identyfikacja obszarów osuwiskowych na podstawie cyfrowych modeli wysokości o dużej rozdzielczości}

Znaczący postęp w rozpoznawaniu i wyznaczaniu granic obszarów objętych deformacjami stoku typu osuwiskowego umożliwiło udostępnienie wysokorozdzielczych danych wysokościowych. Dane cyfrowe pochodzące z lotniczego skaningu laserowego (ang. ASL - airborne laser scanning), kojarzonego w Polsce częściej z pojęciem LiDAR (ang. Light Detection and Ranging), stały się w krótkim czasie podstawowym i niemal doskonałym źródłem wiedzy o ukształtowaniu rzeźby terenu. W Polsce blisko $80 \%$ powierzchni kraju ma pokrycie tego typu danymi (dane CODGiK), co na tle innych państw uznać można za przypadek szczególny. W państwowym zasobie geodezyjnym znalazły się wyniki skaningu prowadzonego w latach 2011-2014 na potrzeby Informatycznego Systemu Osłony Kraju przed nadzwyczajnymi zagrożeniami (ISOK). Należy jednak podkreślić, że w odniesieniu do Polski południowo-zachodniej dane tego typu dostępne były wcześniej dla fragmentów obszarów górskich, w tym sudeckich parków narodowych (Karkonoskiego Parku Narodowego, Parku Narodowego Gór Stołowych) i Leśnego Kompleksu Promocyjnego (LKP) Sudety Zachodnie, a także dla wybranych miast, np. Wrocławia (Knapik i in. 2009, Migoń i in. 2013, Kasprzak, Traczyk 2014).

Istotą metody pomiarowej LiDAR jest detekcja odbicia wiązki lasera od obiektów terenowych. Według „Raportu dostawy” (2011) danych dla ISOK próbkowanie laserem na badanym terenie miało gęstość około 6-9 punktów na $\mathrm{m}^{2}$, średni błąd wysokościowy wynosił w zależności od sekcji 0,05-0,15 m, a błąd maksymalny nie przekraczał 0,3 m. Próbkowanie z gęstością kilku punktów na $\mathrm{m}^{2}$ daje możliwość otrzymania złożonej chmury punktów, daleko idącego jej przetwarzania i wyodrębniania z niej poszczególnych warstw. Jedną z nich jest poziom gruntu otrzymany po usunięciu odbić błędnych oraz odbić lasera od elementów pokrycia terenu. Model taki zwany jest w literaturze bare ground lub bare earth. Do wizualizacji powierzchni i dalszego modelowania dane cyfrowe pod postacią zbioru punktów transformowane są do postaci rastrowej. Wyjściowy, rastrowy model pochodzący z przetwarzania danych LiDAR o gęstości próbkowania gruntu 4-6 punktów na $\mathrm{m}^{2}$ ma $\mathrm{z}$ reguły rozdzielczość $1 \times 1$ m. Tak duża rozdzielczość sprawia, że dostrzegalne stają się elementy terenu niemożliwe do uchwycenia na tradycyjnych materiałach kartograficznych. Modele tego typu są także milowym krokiem w stosunku do wcześniejszych numerycznych modeli terenu (NMT) pochodzących z digitalizacji poziomic na mapach. Sztandarowy, i zarazem najlepszy produkt tego typu w Polsce, model DTED-2, opracowany na podstawie map w skali 1:50 000 i 1:25 000, miał rozdzielczość około $30 \times 30 \mathrm{~m}$.

Wysokorozdzielcze modele pochodzące $\mathrm{z}$ danych LiDAR nie są jednak wolne od wad, do których należy szereg błędów pojawiających się na etapie zbierania i przetwarzania danych. Ich jakość jest wysoce zależna od algorytmów przetwarzania chmury punktów oraz naturalnego pokrycia terenu. Stąd też jakość odwzorowania powierzchni na obszarach porośniętych gęstym lasem nie jest tak dobra, jak na obszarach bezleśnych.

Na silnie zalesionym terenie Gór Kamiennych obraz uzyskany dzięki danym LiDAR dał jednak możliwość zarówno kompleksowej oceny stopnia przekształcenia stoków przez ruchy masowe, jak i wyróżnienia detali morfologii osuwiskowej w sposób niemożliwy do uchwycenia z poziomu gruntu, a w szczególności uzyskania kompletnego obrazu przestrzennego zasięgu stref deformacji stoku. Dane LiDAR pozwalają bowiem w sposób bardzo precyzyjny wskazać granice pomiędzy częściami stoku 

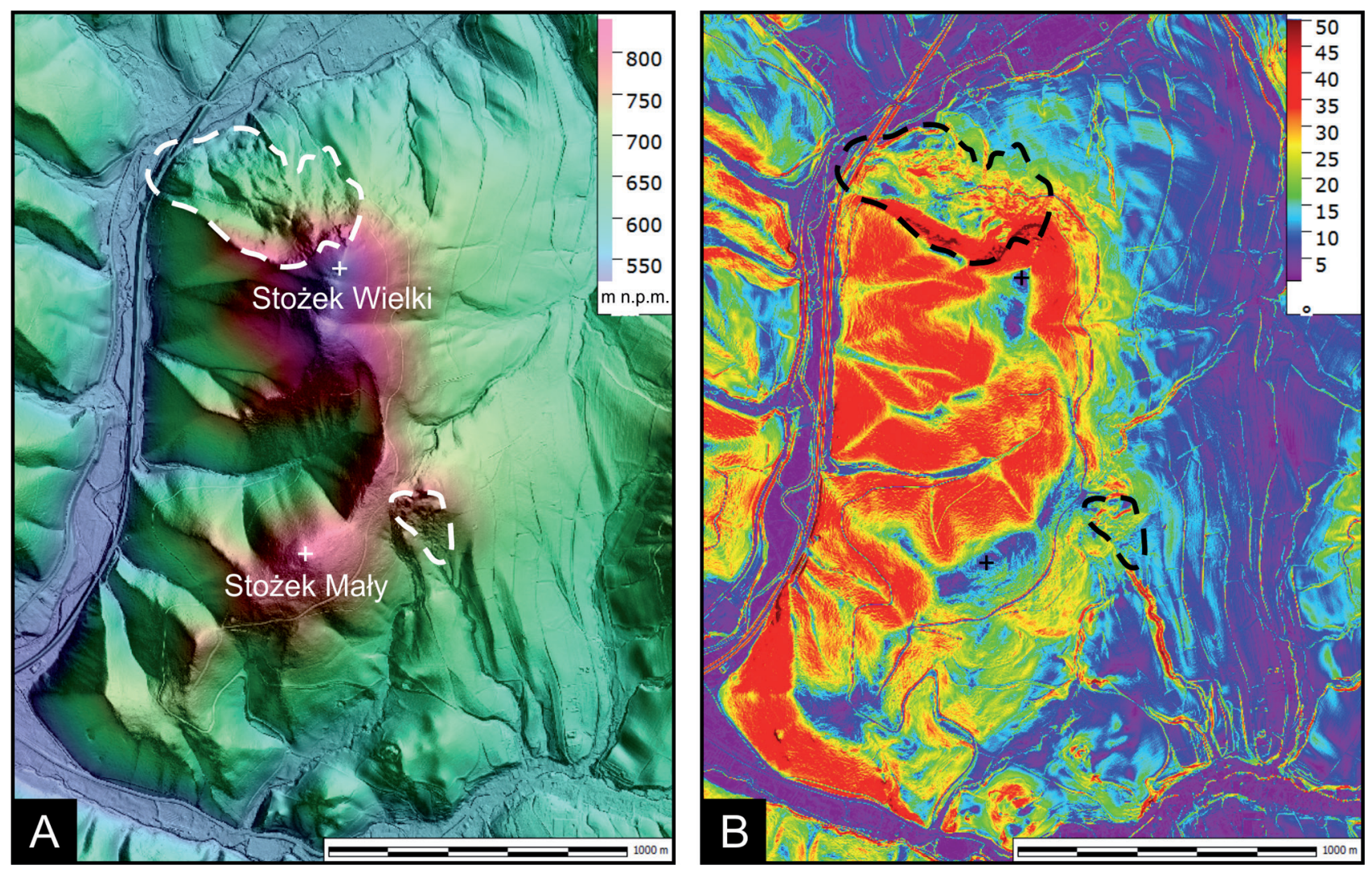

Ryc. 4. Różnice w rzeźbie powierzchni stokowych kształtowanych przez różne procesy powierzchniowe na przykładzie masywu Stożka Wielkiego w Górach Suchych

A - cieniowany model reliefu, B - mapa spadków, w obu przypadkach na podstawie danych LiDAR. Przerywaną linią zaznaczono obrysy terenów osuwiskowych, pozostałe wyrównane powierzchnie stokowe były kształtowane przez soliflukcję i pełzanie gruntu

Fig. 4. Morphological differences between slope surfaces moulded by different geomorphic processes, on the example of Stożek Wielki massif in the Suche Mts

A - shaded relief model, B - slope map, both using LiDAR data. Dashed lines indicate the extent of landslide-affected terrains. The remaining slopes have been modelled by solifluction and soil creep

objętymi wielkoskalowymi ruchami masowymi i tymi, które były kształtowane wyłącznie przez płytkie, przypowierzchniowe przemieszczenia typu pełzającego i soliflukcyjnego (ryc. 4). Dzięki temu możliwe było wyznaczenie konturów osuwisk i form spływowych, a przez to ocena całkowitej powierzchni objętej przez ruchy masowe (Migoń i in. 2014a). Otrzymane materiały pozwoliły też na weryfikację wyników wcześniejszego kartowania terenowego, niekiedy ukazując obraz nieco odmienny niż uprzednio prezentowany w literaturze (ryc. 5).

$\mathrm{W}$ trakcie badań terenowych okazało się również, że nie wszystkie drobne formy rzeźby znajdują odzwierciedlenie w danych LiDAR, co jest zgodne z wcześniejszymi doświadczeniami z Karkonoszy i Gór Stołowych (Migoń $i$ in. 2013). Elementem praktycznie nieobecnym na modelach są duże bloki skalne na stokach i w dnach dolin, nawet te o wymiarach rzędu $3 \times 2 \mathrm{~m}$, a więc teoretycznie w zakresie rozdzielczości skanowania laserowego. Bloki takie, o allochtonicznym charakterze, są ważnym wskaźnikiem transportu masowego $\mathrm{w}$ dnach dolin i pozwalają wyznaczyć zasięg osuwisk nawet wówczas, gdy inne elementy morfologii jęzorów zostały całkowicie zatarte (zdenudowane). Taka sytuacja ma miejsce u wylotu bezimiennej doliny pod Garbatką w Sokołowsku, gdzie jedynie dziesiątki rezydualnych bloków tufu riolitowego świadczą o dawnym zasięgu osuwiska lub spływu (Kasprzak i in. 2014, Migoń i in. 2014b). Jego wyznaczenie wyłącznie na podstawie danych LiDAR byłoby niemożliwe.

\section{Morfologia i zróżnicowanie osuwisk w Górach Kamiennych - podsumowanie}

Terenowe kartowanie geomorfologiczne, wspomagane analizą rzeźby na podstawie NMT dużej rozdzielczości i uwzględniające wyniki kartowania geologicznego (wskazanie allochtonicznych elementów głazowych i blokowych oraz większych, zwartych pakietów skalnych), nie pozostawia wątpliwości, że stoki Gór Kamiennych, a w szczególności Gór Suchych, zostały w znaczącym stopniu przekształcone przez procesy osuwiskowe.

Dane LiDAR pozwalają na weryfikację i rewizję dotychczasowych poglądów o charakterze osuwisk i działania te są obecnie prowadzone $\mathrm{w}$ ramach ponownego kartowania terenowego. Powinny one zaowocować opracowaniem typologii osuwisk Gór Kamiennych. Niemniej już na obecnym etapie badań można potwierdzić, że przemieszczenia osuwiskowe miały bardzo różny charakter. 

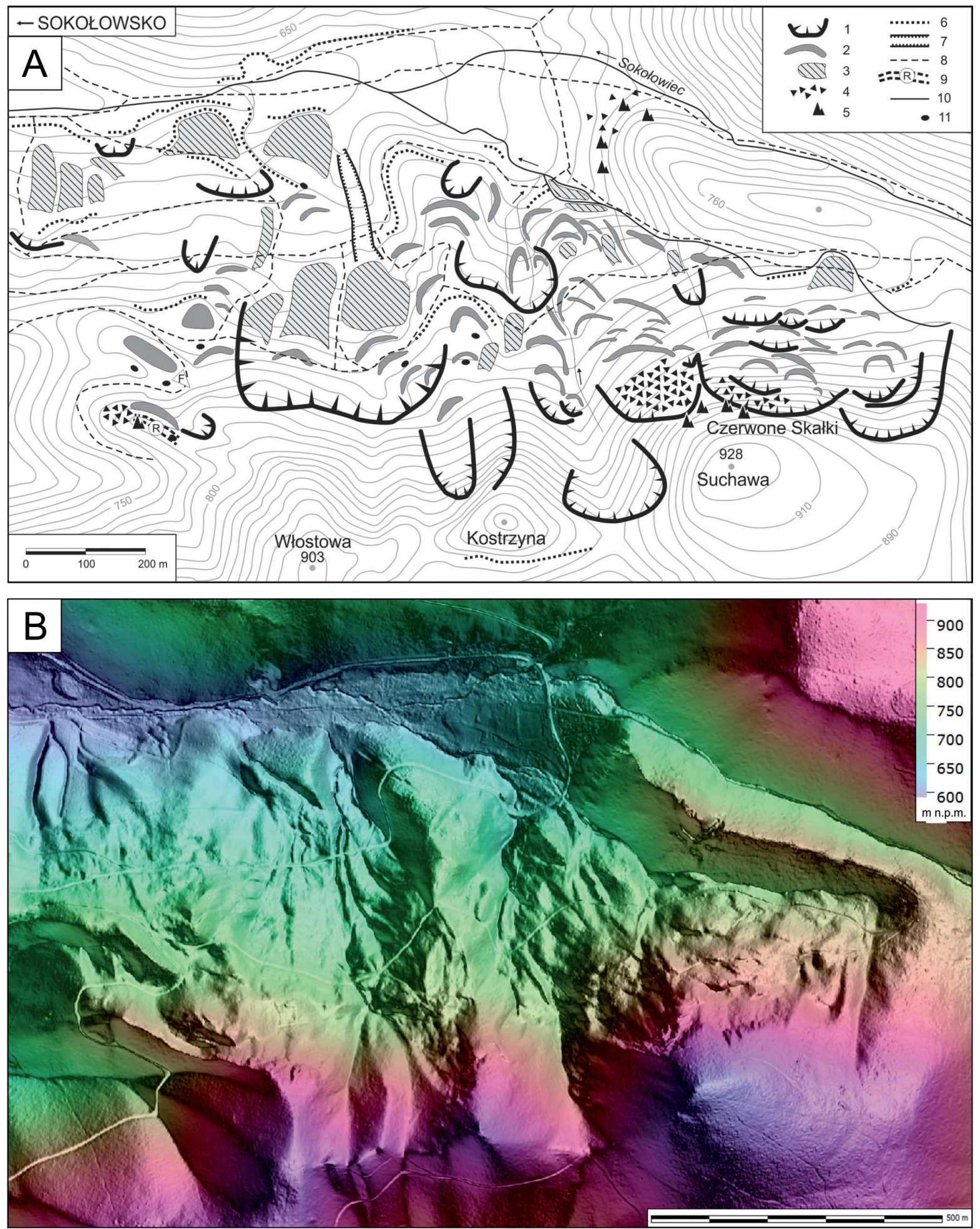

Ryc. 5. Porównanie wyników kartowania geomorfologicznego prowadzonego na obszarze leśnym w masywie Włostowej-Suchawy w Górach Suchych (A) oraz mapy hipsometrycznej z podkładem cieniowanego reliefu (azymut $45^{\circ}$, kąt pionowy oświetlenia $45^{\circ}$, przewyższenie 6) wykonanej na podstawie numerycznego modelu terenu o rozdzielczości $1 \times 1 \mathrm{~m}(\mathrm{~B})$. Prezentowane wyniki kartowania pochodzą z pracy Kasprzaka i Traczyka (2012), cyfrowy model wysokościowy został wykonany na podstawie danych LiDAR w $2013 \mathrm{r}$. 1 - krawędzie nisz, 2 - grzbiety poprzeczne, 3 - strefy akumulacji związanej z ruchami masowymi, 4 - rumowiska skalne, 5 - skałki, 6 - krawędzie różnej genezy, 7 - rynna erozyjna, 8 - drogi, 9 - rozpadlina skalna (rów grzbietowy), 10 - cieki, 11 - zagłębienia bezodpływowe suche i wypełnione wodą

Fig. 5. Comparison of results of geomorphological mapping in the forested terrain of the Włostowa - Suchawa ridge in the Suche Mts (A) and hypsometric map overlain on shaded relief model (sun azimuth $45^{\circ}$, sun elevation angle $45^{\circ}$, vertical exaggeration $\times 6$ ) from $1 \times 1 \mathrm{~m}$ resolution LiDAR data (B). Geomorphological map after Kasprzak \& Traczyk (2012), DEM from 2013

1 - head scarps, 2 - transverse ridges, 3 - colluvial deposition due to mass movement, 4 - rock debris, 5 - rock crags, 6 - scarps of various origin, 7 - erosional furrow, 8 - roads, 9 - rock cleft (trench), 10 - watercourses, 11 - closed depressions, dry and water-filled 
Układ form wskazuje na występowanie następujących typów osuwisk:

- głębokich osuwisk rotacyjnych, z łukowatą lub prostoliniową skarpą główną i jednym lub kilkoma wstecznie przechylonymi pakietami skalnymi poniżej; taki układ form występuje m.in. pod Dzikowcem Wielkim i pod Suchawą, we wschodniej części północnego sto$\mathrm{ku}$;

- osuwisk typu rotacyjnego, z łukowatą skarpą główną, ale całkowicie zdezintegrowanym pakietem, który uległ przemieszczeniu; w takich przypadkach nie występuje typowy płat osuwiskowy, tylko pagórkowata strefa koluwiów w środkowej/dolnej części stoku; tego typu przemieszczenia miały miejsce na stokach Granicznika;

- osuwisk ześlizgowych (translacyjnych), z prostoliniową skarpą główną, niekiedy rowami rozpadlinowymi w górnej części osuwiska oraz zdezintegrowaną częścią dolną; taki charakter miały zapewne osuwiska pod Włostową i Jeleńcem Małym;

- osuwisk spływowych (flowslide), w których materiał przemieszczał się dnem doliny, a morfologicznym efektem są falisto-pagórkowate, wypukłe wypełnienia dolin 1. rzędu, m.in. pod Garbatką, Rogowcem i Lesistą Wielką;

- osuwisk o złożonej morfologii, z elementami typowymi dla przemieszczeń różnego typu. Wyrazistość form nie zawsze jednak pozwala jednoznacznie rozstrzygnąć, czy przemieszczenia zachodziły względnie równocześnie, czy też w następstwie czasowym. Niemniej w kilku przypadkach następstwo zdarzeń jest ewidentne, tak jak w obrębie formy osuwiskowej powstałej na wschodnich stokach Rogowca, gdzie wielkoskalowe przewracanie pakietów skalnych objęło skarpę główną wcześniejszego osuwiska (Pulinowa 1972), lub pod Suchawą, gdzie intensywne odpadanie materiału ze skarpy głównej doprowadziło do powstania kilku generacji usypisk nałożonych na starsze koluwia osuwiskowe (Kacprzak i in. 2013).

Niezbędne jest także odnotowanie, że niektóre osuwiska trudno jednoznacznie zakwalifikować do podstawowych kategorii przemieszczeń grawitacyjnych wyróżnianych w literaturze. Trudności te mogą wynikać zarówno ze złożonej natury ruchów masowych, jak i znacznego stopnia zatarcia pierwotnej morfologii stref oderwania, transportu i akumulacji materiału przemieszczanego grawitacyjnie.

\section{Wiek osuwisk}

\section{Wykorzystanie właściwości pokrywy glebowej do określenia wieku ruchów masowych}

Ruchy masowe, transformując pierwotną powierzchnię stoku, modyfikują kierunek i intensywność procesów glebotwórczych. Powstawanie nowych form i wzrost urozmaicenia mezo- i mikrotopografii stoku warunkuje znaczne zróżnicowanie stosunków wodnych w glebie, jak również nierównomierną akumulację materii organicznej. W rezultacie pokrywa glebowa stoków osuwiskowych charakteryzuje się występowaniem większej ilości typów gleb i bardziej złożoną strukturą niż na stokach nie objętych ruchami masowymi, na których powierzchni procesy pedogenetyczne działają w sposób bardziej jednorodny (Hradecký i in. 2008).

Analiza zróżnicowania pokrywy glebowej może być pomocna $\mathrm{w}$ interpretacji genezy form występujących na stokach, jednak dla datowania ruchów masowych największe znaczenie ma fakt, że zmieniają one czas trwania pedogenezy na obszarach, gdzie występują. Na skutek odsłaniania podłoża skalnego lub zwietrzeliny nie objętej wcześniej procesami glebotwórczymi, przemieszczania i mieszania materiału zwietrzelinowo-glebowego gleby na stokach objętych ruchami masowymi otrzymują nowy czas zero (ang. time zero), rozumiany jako moment, w którym rozpoczyna się działanie procesów glebotwórczych (Schaetzl, Anderson 2005). W największym stopniu dotyczy to ruchów masowych o charakterze spływowym (ang. flowslides) i spływów gruzowych, dzięki którym materiał wcześniej objęty pedogenezą zostaje przemieszczony i wymieszany, tworząc substrat dla nowej generacji gleb o bliższym współczesności czasie zero. W mniejszym stopniu dotyczy to klasycznych osuwisk typu rotacyjnego, w których obrębie przemieszczane są bloki skał podłoża wraz z istniejącą, często nienaruszoną, pokrywą glebową (Birkeland 1999). W tym przypadku znaczące zmiany czasu trwania pedogenezy i, w konsekwencji, możliwość wykorzystania właściwości gleb do datowania przemieszczeń grawitacyjnych dotyczą przede wszystkim odmłodzonych skarp głównych.

Przykładem wykorzystania analizy gleb do datowania osuwisk są badania prowadzone na terenie Jury Szwabskiej (Bibus i in. 2001, Terhorst 2007) oraz Pre-Alp (Terhorst i in. 2009). W celu określenia wieku i odróżnienia osuwisk holoceńskich od plejstoceńskich zastosowano analizę porównawczą typów gleb występujących w obrębie osuwisk oraz sekwencji typów gleb w katenach nie objętych ruchami masowymi. Istotne znaczenie przypisano także występowaniu w badanych profilach utworów peryglacjalnych - warstw cover beds (sensu Kleber 1997, Semmel, Terhorst 2010), identyfikowanych przede wszystkim dzięki zawartości lessu będącej efektem oddziaływania procesów eolicznych i popiołów wulkanicznych z erupcji wulkanu Laacher See na wyżynie Eifel w zachodnich Niemczech, która miała miejsce przed około 12,9 tys. lat temu.

W badaniach gleb obszarów osuwiskowych kluczowe znaczenie ma porównywanie pokrywy glebowej stoków przekształconych przez ruchy masowe ze stabilnymi (Bibus $i$ in. 2001, Hradecký $i$ in. 2008). Ze względu jednak na ogromne zróżnicowanie właściwości gleb, będące wypadkową różnorodności materiału macierzystego (podłoża skalnego i pokryw stokowych) oraz roślinności silnie wpływającej na przebieg pedogenezy, trudno mówić o istnieniu sekwencji typów gleb charakterystycznych 


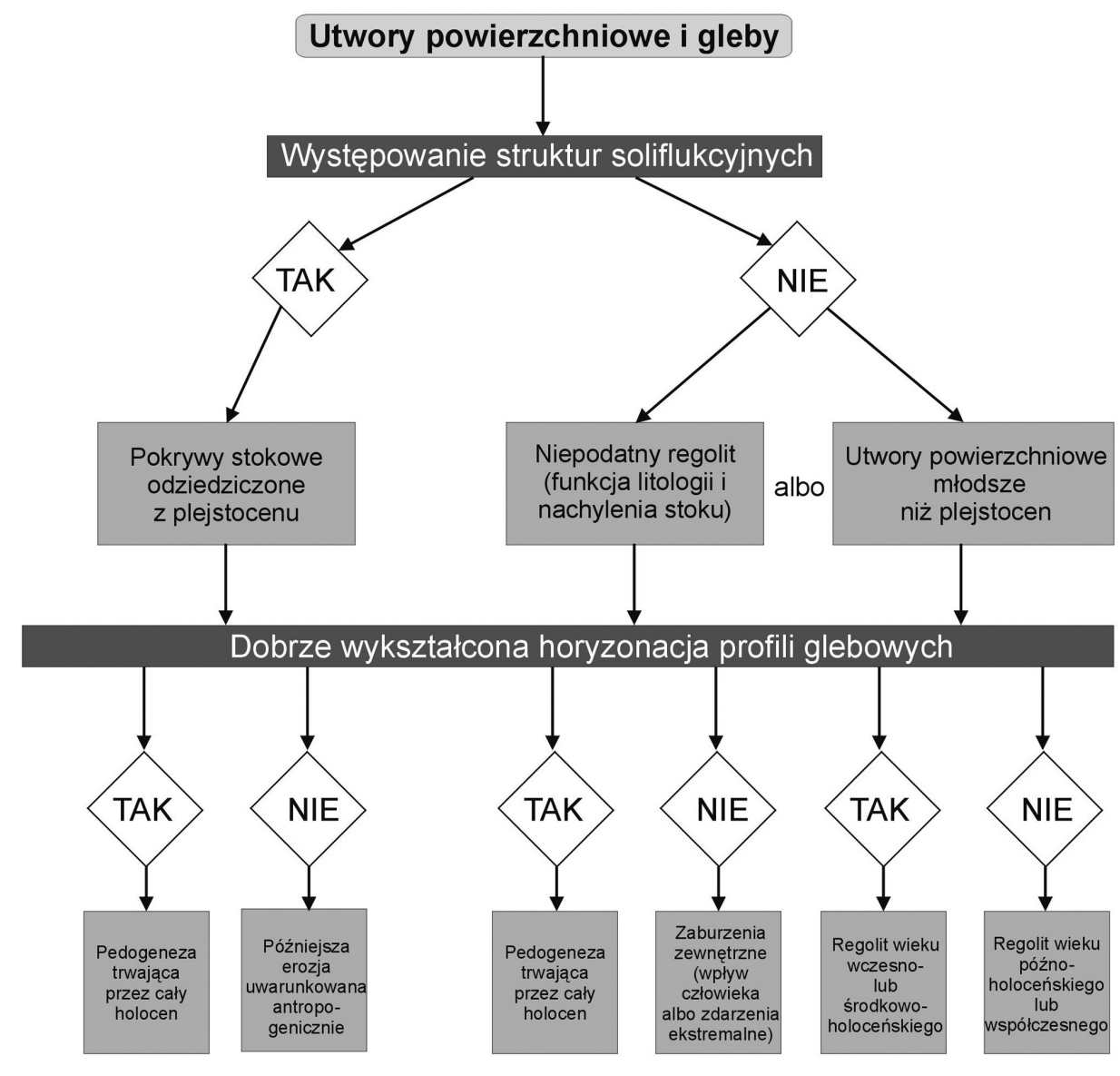

Szukana cecha

Wyjaśnienie

Ryc. 6. Algorytm pozwalający na identyfikację partii stoków objętych przez holoceńskie osuwiska na podstawie właściwości utworów powierzchniowych i gleb (za: Kacprzak i in. 2013, zmienione).

Fig. 6. Algorithm to allow identification of hillslopes affected by landslides in the Holocene, using properties of cover deposits as a diagnostic tool (after Kacprzak et al. 2013, modified).

dla stoków osuwiskowych, uniwersalnej w skali ponadregionalnej. Równolegle istnieje wiele klasyfikacji gleb o charakterze narodowym i zamierzonych jako międzynarodowe - systemy te wykorzystują wprawdzie zbliżone kryteria, ale nie w sposób jednakowy, a dodatkowo podlegają stałej modyfikacji. W związku z tym zastosowanie różnych systemów klasyfikacyjnych może owocować różnicami w pozycji systematycznej badanych gleb, jak również w uzyskiwanym w konsekwencji obrazie kartograficznym. Wydaje się zatem, że w badaniach o charakterze interdyscyplinarnym, takich jak datowanie ruchów masowych, najlepsze efekty można uzyskać, analizując nie tyle pozycję systematyczną gleb, ile zróżnicowanie ich właściwości i zaawansowania pedogenezy wyrażone takimi cechami, jak głębokość profilu, zawartość materii organicznej, rozkład zawartości węgla organicznego w profilu glebowym, obecność i miąższość poszczególnych poziomów genetycznych, a przede wszystkim stopień zróżnicowania profilu na poziomy genetyczne (horyzonację) (Kacprzak i in. 2011, 2013, Musielok, Kacprzak 2012). Podobnie ze względu na różnice regionalne nie wydaje się zasadne mechaniczne przenoszenie modelu cover beds na wszystkie stoki obszarów górskich Europy Środkowej (Kacprzak i in. 2013, Migoń, Kacprzak 2014).

Bazując na powyższych przesłankach, w trakcie badań w Górach Kamiennych opracowano stosunkowo prosty algorytm pozwalający na datowanie różnych generacji ruchów masowych w oparciu o obecność reliktowych, plejstoceńskich cech utworów powierzchniowych oraz horyzonację gleby, rozumianą jako stopień rozwoju sekwencji poziomów genetycznych (ryc. 6). Biorąc pod uwagę czwartorzędową historię rozwoju środowiska Sudetów i panujące na ich obszarze surowe warunki peryglacjalne w okresie ostatniego maksimum glacjalnego, początek aktualnej pedogenezy (czas zero) należy wiązać ze zmianą klimatu (ociepleniem) na przełomie plejstocenu i holocenu. Zatem jeśli osuwiska powstały przed holocenem, właściwości gleb na obszarach osuwiskowych i poza nimi powinny być zbliżone. Jeśli osuwiska są natomiast młodsze, holoceńskie, czas oddziaływania procesów glebotwórczych w ich obrębie był krótszy, co powinno znaleźć odzwierciedlenie w różnicach stopnia 
rozwoju gleb pomiędzy obszarami osuwiskowymi a sąsiadującymi z nimi stokami stabilnymi, które w holocenie nie były objęte ruchami osuwiskowymi.

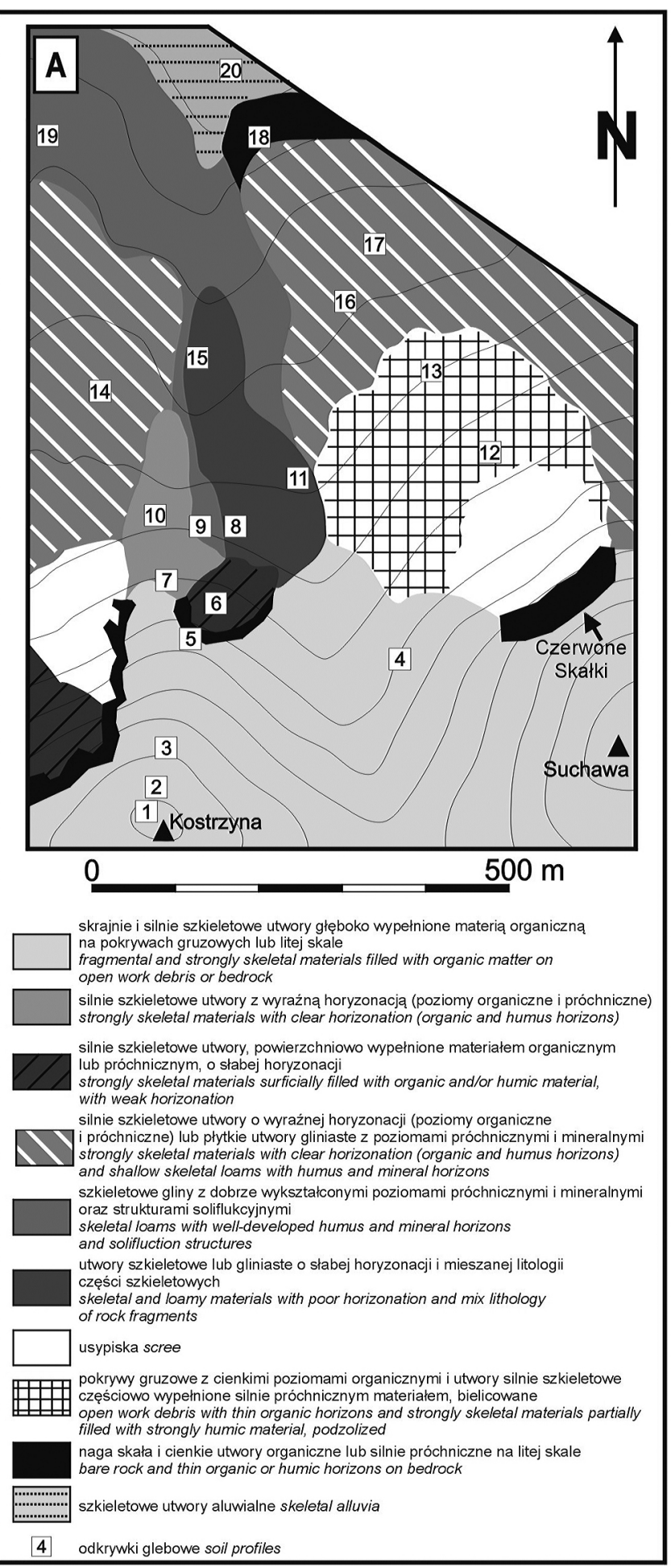

\section{Wykształcenie gleb a wiek osuwisk w Górach Kamiennych}

Badania gleboznawcze obejmowały wykonanie i opis odkrywek glebowych (razem blisko 50) oraz laborato-

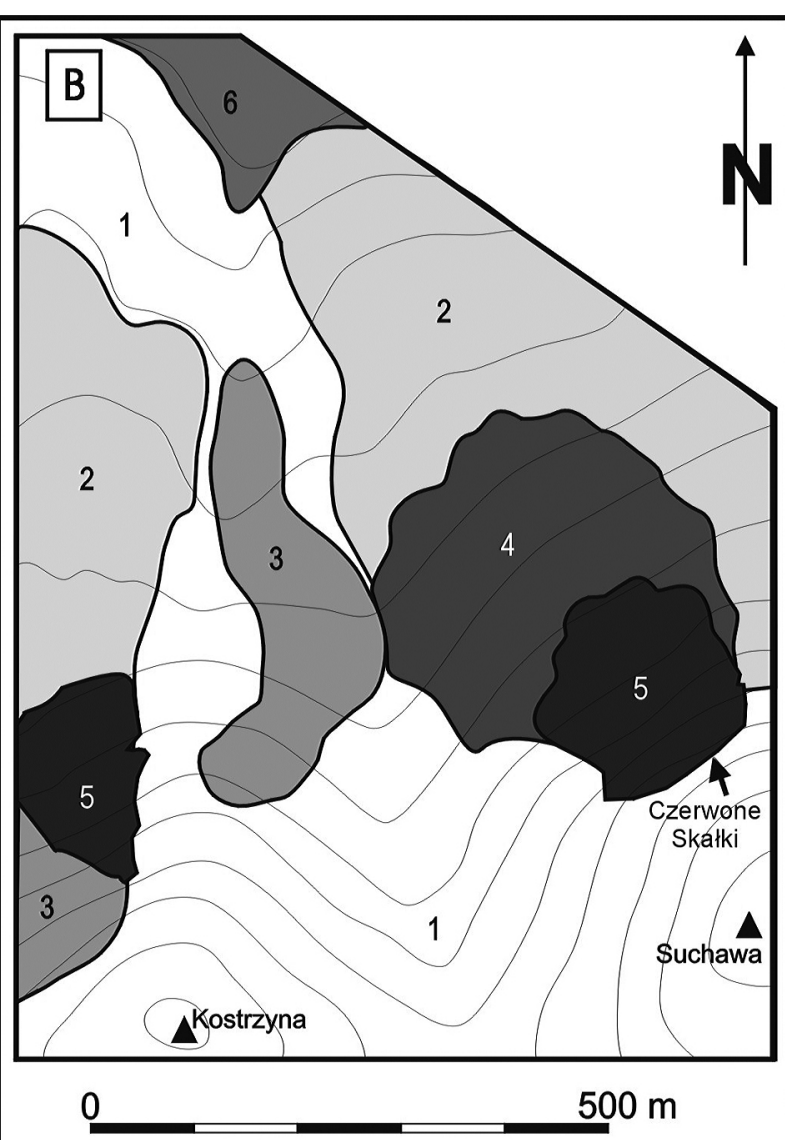

Obszary (areas):

1 w pełni stabilne $w$ holocenie

entirely stable in the Holocene

2 względnie stabilne po wczesnym holocenie

2 relatively stable after the early Holocene

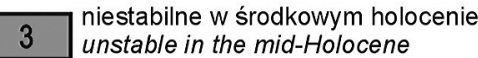

4 niestabilne w późnym holocenie unstable in the late Holocene

5 aktualnie niestabilne currently unstable

6 aluwia

Ryc. 7. Zróżnicowanie właściwości utworów powierzchniowych i gleb na północnych stokach Kostrzyny i Suchawy w Górach Suchych (A) oraz mapa względnego wieku form (B) uzyskana dzięki analizie tego zróżnicowania za pomocą algorytmu ukazanego na rycinie 6 (za: Kacprzak i in. 2013, zmienione)

Fig. 7. Diversity of cover deposits and soil properties on the northern slopes of Mt Kostrzyna and Mt Suchawa in the Suche Mts (A) and the map of relative ages of landforms (B), derived from an analysis of the above diversity using the algorithm presented in Fig. 6 (after Kacprzak et al. 2013, modified) 
ryjne analizy najważniejszych właściwości materiału glebowego pobranego w odkrywkach. Laboratoryjnie oznaczano skład granulometryczny części ziemistych, $\mathrm{pH}$, zawartość węglanów, zawartość węgla organicznego oraz stratę żarową. Barwę materiału glebowego opisywano za pomocą skali Munsella w stanie wilgotnym i suchym. Objętościową zawartość, wielkość oraz ułożenie części szkieletowych szacowano w terenie, ich litologię natomiast analizowano w laboratorium. W trakcie badań znaczną uwagę poświęcano opisowi struktury gleby, czyli wielkości, kształtu i trwałości agregatów części ziemistych. Uzyskane dane oraz kartowanie terenowe pozwoliły na stworzenie map obrazujących przestrzenne zróżnicowanie właściwości utworów powierzchniowych (pokrywy glebowej) w wybranych fragmentach Gór Kamiennych, na stokach Kostrzyny, Suchawy, Garbatki i Rogowca.

Badania na stokach Kostrzyny i Suchawy w Górach Suchych, zbudowanych w głównej mierze z silnie spękanych riolitów, wykazały ogromne zróżnicowanie właściwości gleb silnie nawiązujące do występujących tam form związanych z ruchami masowymi (Kacprzak i in. 2013). W partiach stoków pozbawionych form osuwiskowych występowały gleby o dobrze rozwiniętych sekwencjach poziomów genetycznych głównych i przejściowych, cechujących się znaczną zawartością materii organicznej, często do głębokości kilkudziesięciu centymetrów, oraz, w przypadku profili położonych $\mathrm{w}$ dolnych partiach stoków - występowaniem peryglacjalnych struktur soliflukcyjnych. Gleby zajmujące obszar osuwiskowy wykazywały natomiast wyraźnie słabsze zróżnicowanie na poziomy genetyczne oraz mniejszą zawartość materii organicznej, koncentrującej się bliżej powierzchni. Nie stwierdzano w nich również występowania struktur soliflukcyjnych, a część profili wykazywała wręcz inicjalne stadium rozwoju, w którym na materiale skalnym obserwowano jedynie obecność poziomów organicznych lub słabo wykształconych, płytkich poziomów próchnicznych. Analiza przestrzennego zróżnicowania właściwości gleb pozwoliła na określenie wieku ruchów masowych jako holoceński, jak również wskazała na istnienie kilku generacji osuwisk (ryc. 7).

Podobne rezultaty uzyskano w rejonie Rogowca, gdzie ze zróżnicowaną wyrazistością form osuwiskowych korespondowały znaczące różnice właściwości gleb (Kacprzak, Migoń 2013). Gleby w obrębie jęzora osuwiska charakteryzowały się słabym stopniem rozwoju profilu glebowego (A-C), niską zawartością węgla organicznego i wykształceniem struktury agregatowej zaledwie do głębokości nie przekraczającej 40-50 cm. Pomiędzy stabilnymi partiami stoków a niszą osuwiskową, na odcinku zaledwie około $100 \mathrm{~m}$, stwierdzono znaczace różnice w wykształceniu gleb. Są one wyrażone m.in. spłyceniem profilu glebowego i pozbawieniem go górnej warstwy o charakterystycznych cechach soliflukcyjnych i grubości kilkudziesięciu centymetrów, która jest obecna w profilach poza niszą, co wskazuje na holoceński wiek ruchów masowych.

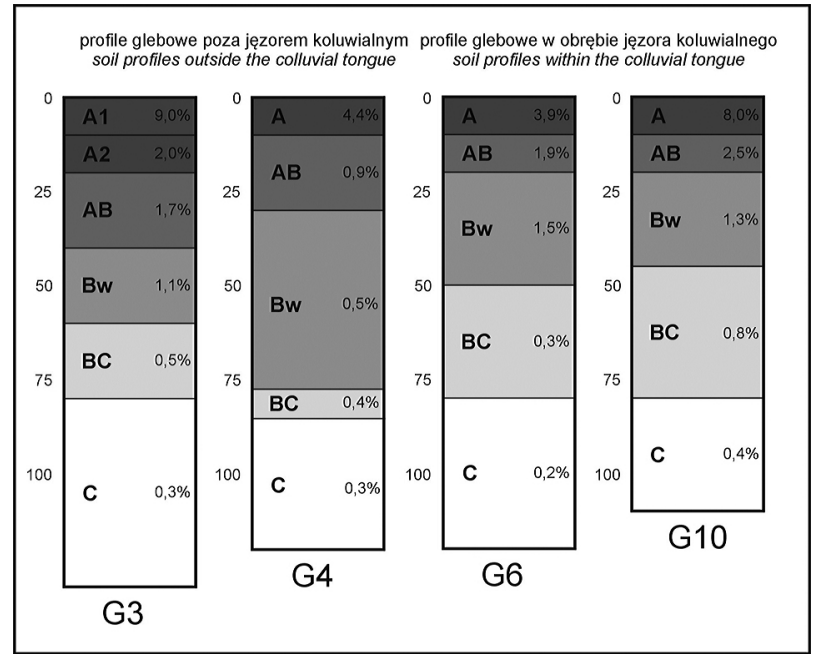

Ryc. 8. Horyzonacja i zawartość węgla organicznego w profilach glebowych z rejonu Garbatki w Górach Suchych; pominięto poziomy organiczne; głębokość profili w centymetrach (za: Migoń i in. 2014b)

Fig. 8. Horizonation and organic carbon content in soil profiles in the vicinity of Mt Garbatka in the Suche Mts; organic horizons not included; depth of soil profiles in centimeters (after Migoń i in. 2014b)

Odmienne wnioski na temat wieku osuwisk można natomiast wyciągnąć $\mathrm{z}$ analizy właściwości gleb w rejonie Garbatki (Migoń i in. 2014b). Zdecydowana większość badanych profili wykazywała bardzo zbliżony rozwój poziomów glebowych i podstawowych właściwości, w tym rozkład zawartości węgla organicznego w profilu. Typowa sekwencja mineralnych poziomów genetycznych w tych glebach to A-(AB)-Bw-BC-C (ryc. 8). Przejścia pomiędzy poziomami genetycznymi mają charakter stopniowy, a poziomy cambic $(\mathrm{Bw})$ identyfikowano przede wszystkim na podstawie rozwoju struktury glebowej, ponieważ, ze względu na czerwonawą barwę tufów stanowiących materiał macierzysty, proces brunatnienia nie miał tak znaczącego wpływu na barwę gleby jak zazwyczaj. Profile glebowe położone wyżej na stoku, podścielone spękanym tufem o strukturze open work, charakteryzują się większą zawartością węgla organicznego i przejawami procesu bielicowania (nieznaczne wmycie próchnicy i powstanie poziomów $\mathrm{B}(\mathrm{hs})$ oraz ślady wymywania związków żelaza w postaci rozjaśnionych powierzchni klastów w poziomach $\mathrm{A}(\mathrm{E})$ ). Właściwości i horyzonacja profili glebowych w obrębie jęzora koluwialnego i poza nim są bardzo zbliżone i nie zaznacza się zróżnicowanie pokrywy glebowej pomiędzy obszarem osuwiskowym i przyległymi partiami stoków, co ma miejsce na terenach przekształconych przez osuwiska w holocenie (Hradecký $\mathrm{i}$ in. 2008, Kacprzak i in. 2013). Ponadto, chociaż nie stwierdzono występowania struktur soliflukcyjnych w profilach glebowych w obrębie osuwiska (np. G6, G9, G10, G11), właściwości gleb i horyzonacja są bardzo zbliżone do obserwowanych w profilach położonych na sąsiadujących z osuwiskiem stokach stabilnych $(\mathrm{G} 3, \mathrm{G} 4)$, w których stwierdzono charakterystyczne dla działania procesów soliflukcyjnych ułożenie klastów szkieleto- 
Tabela 2. Wyniki datowań radiowęglowych osadów organicznych z zagłębień bezodpływowych w obrębie osuwisk Gór Kamiennych (za: Synowiec 2005, s. 165)

Table 2. Results of radiocarbon datings of organic deposits collected from closed depressions within landslide terrains in the Kamienne Mountains (after Synowiec 2005, p. 165)

\begin{tabular}{lcccc}
\hline $\begin{array}{c}\text { Lokalizacja } \\
\text { Location }\end{array}$ & $\begin{array}{c}\text { Głębokość pobrania }(\mathrm{m}) \\
\text { Depth of sampling }(\mathrm{m})\end{array}$ & $\begin{array}{c}\text { Wiek BP } \\
\text { Age before present (BP) }\end{array}$ & $\begin{array}{c}\text { Wiek kalibrowany (BC) } \\
\text { Calibrated age (BC/AD) }\end{array}$ & $\begin{array}{c}\text { Kod laboratoryjny próbki } \\
\text { Sample laboratory code }\end{array}$ \\
\hline Jeleniec Mały 1 & 1,0 & $2340 \pm 70$ & $800-200$ & Gd-16284 \\
Jeleniec Mały 2 & 1,8 & $1330 \pm 120$ & $400-1000$ AD $^{2}$ & Gd-18287 \\
Jeleniec Mały 2 & 1,2 & $3280 \pm 40$ & $1690-1440$ & GdA-277 \\
Rogowiec & 1,4 & $5835 \pm 60$ & $4850-4540$ & GdA-288 \\
\hline
\end{tabular}

${ }^{1}$ Kalibracja z prawdopodobieństwem 95,4\%, przy użyciu programu OxCal v. 3.9.

${ }^{2}$ Synowiec uważa ten wiek za prawdopodobnie zbyt młody.

wych. Można zatem przyjąć, że wszystkie badane profile podlegały pedogenezie o zbliżonym czasie trwania, obejmującej holocen, zatem osuwisko Garbatka powstało jeszcze w plejstocenie.

\section{Inne wskaźniki wieku osuwisk}

W Górach Kamiennych zostały wykonane jedynie nieliczne oznaczenia wieku bezwzględnego osadów w obrębie form osuwiskowych. W niepublikowanej rozprawie doktorskiej Synowca (2005) przedstawiono wyniki datowań pięciu prób materiału organicznego pozyskanego ze spągowych partii osadów wypełniających jeziorka osuwiskowe pod Rogowcem i Jeleńcem Małym. Wszystkie daty są holoceńskie i zawierają się w przedziale od 5800 lat BP po historyczną datę 1300 lat BP (tab. 2). W świetle zasad i metodyki interpretacji takich datowań wskazują one na minimalny wiek aktywności osuwiskowej (przy nieznanym czasie potrzebnym na uszczelnienie dna zagłębienia bezodpływowego i rozpoczęcie akumulacji materiału organicznego), przy czym nie ma możliwości rozstrzygnięcia, czy była to reaktywacja starszej formy, czy powstało całkowicie nowe osuwisko. Należy przy tym dodać, że pod osadami organicznymi wypełniającymi misy jeziorek osuwiskowych w Górach Suchych, sięgającymi do głębokości 25-35 cm, nawiercono warstwy drobnoziarnistych osadów mineralnych różnej grubości (od 10 do $90 \mathrm{~cm}$ ), których nie datowano. Nie ulega jednak wątpliwości, że przynajmniej niektóre osuwiska wykazywały aktywność w środkowym i młodszym holocenie, co jest spójne z wynikami badań pokrywy glebowej. Na niemal współczesną niestabilność stoków wskazują także wyniki datowania pogrzebanych poziomów próchnicznych pod koluwiami spływów gruzowo-błotnych u podnóża Świętej Góry w Lubawce - 1105( \pm 15$)$ BP oraz 1940( \pm 25$) \mathrm{BP}^{1}$.

$\mathrm{Na}$ młody wiek części ruchów masowych może wskazywać także analiza porównawcza charakteru i morfodynamiki stożków usypiskowych tworzących się poniżej skarp głównych, szczególnie pod Suchawą, oraz genetycznie zbliżonych form znajdujących się w innych częściach Sudetów (Remisz i in. 2009, Remisz 2012, Remisz, Bijak 2012). Usypiska o peryglacjalnym pocho-

\footnotetext{
Wyniki datowań uzyskanych przez współautorów tego artykułu (A.K., P.M.) nie zostały jeszcze opracowane, szczegółowa praca na ten temat jest w przygotowaniu.
}

dzeniu, odziedziczone $\mathrm{z}$ plejstocenu, są niemal w pełni ustabilizowane, dostawa materiału ze ścian skalnych jest znikoma, a przemieszczenia gruzu są sporadyczne. Znacznie więcej analogii do stożków usypiskowych na osuwisku pod Suchawą wykazują usypiska poniżej skarpy głównej osuwiska pod Kalwarią w Bardzie, która powstała w 1598 r. Stopień pokrycia roślinnością usypiska w Bardzie jest nawet większy niż analogicznych form pod Suchawą. Jakkolwiek porównanie takie nie upoważnia do postawienia tezy o aktywności osuwiska pod Suchawą w XVI w. lub później, podobieństwo tych dwóch stanowisk może być traktowane jako kolejna przesłanka wskazująca na aktywność przynajmniej części osuwisk w holocenie.

\section{Czy osuwiska Gór Kamiennych wykazują współczesną aktywność?}

\section{Dendrochronologiczne kryteria oceny aktywności osuwisk}

Identyfikacja aktywnych osuwisk jest prosta w przypadku, gdy po szybkim epizodzie ruchu materiału stokowego powstają czytelne w terenie formy osuwiskowe. Wątpliwości w zakresie współczesnej aktywności osuwisk powstają, gdy formy osuwiskowe są słabo widoczne lub zatarte. Do identyfikacji aktywnych osuwisk stosowana jest między innymi metoda dendrochronologiczna. W wyniku nawet nieznacznych przemieszczeń osuwiskowych drzewa porastające stoki osuwiskowe pochylają się wskutek przemieszczeń podłoża. Po wychyleniu pnia z pozycji pionowej wyraźnie zmienia się struktura drewna, którą drzewo wykształca (Alestalo 1971, Shroder 1980), następują również zmiany w przyrostach rocznych drzew (Braam i in. 1987, Krąpiec, Margielewski 2000). Obliczając słoje od pierwszego roku, w którym zidentyfikowano zmiany w strukturze drewna, do ostatniego tzw. przyrostu podkorowego, można ustalić, w którym roku drzewo zostało pochylone, a pośrednio - kiedy wystąpił epizod/epizody osuwania, aczkolwiek już Shroder (1980) zwracał uwagę na możliwe roczne lub dwuletnie opóźnienie reakcji. Dotąd stosowano głównie trzy cechy anatomiczne drewna drzew, które pozwalają zidentyfikować lata aktywności osuwiskowej: dekoncen- 


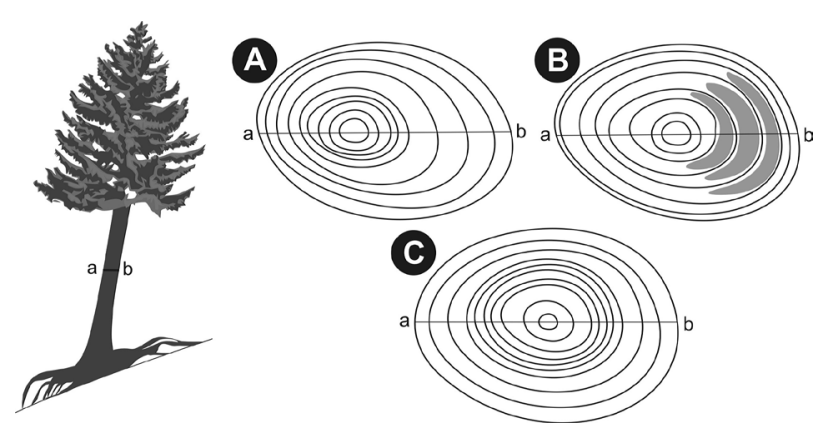

Ryc. 9. Cechy słojów drzew i anatomii drewna, które mogą dokumentować osuwanie

A - dekoncentryczny układ słojów świadczący o ruchu osuwiska zapoczątkowanego 4 lata przed rokiem poboru próby, B - drewno reakcyjne świadczące o ruchach osuwiska występujących 5 lat przed rokiem poboru próby, $\mathrm{C}$ - redukcja przyrostów rocznych trwająca 4 lata i świadcząca o ruchu osuwiska 7 lat przed rokiem poboru próby

Fig. 9. Tree rings patterns and wood anatomy features which can record landsliding

A - eccentric tree growth records landsliding initiated 4 years before sampling, $\mathrm{B}$ - reaction wood records landsliding that occurred 5 years before sampling, $\mathrm{C}$ - four-years long tree ring reduction records landsliding that occurred 7 years before sampling

tryczny przyrost drzewa, drewno reakcyjne i redukcje przyrostów rocznych.

Dekoncentryczność wzrostu drzewa polega na wykształcaniu przyrostów rocznych szerszych z jednej strony i węższych z drugiej, w osi zgodnej z kierunkiem pochylenia pnia drzewa (ryc. 9). Cecha ta pojawia się nawet po niewielkim pochyleniu drzewa, wynoszącym około $2-3^{\circ}$ (Kojs i in. 2012). Zatem jest ona bardzo czułym wskaźnikiem, pozwalającym zidentyfikować nieznaczne ruchy osuwiskowe. Dekoncentryczność przyrostów rocznych może zostać zidentyfikowana poprzez pomiar szerokości przyrostów rocznych i porównanie szerokości poszczególnych słojów przyrostu rocznego występujących po obu stronach pnia, zgodnie z jego nachyleniem (ryc. 9A). Różnice szerokości przyrostów rocznych w tych samych latach wskazują na wystąpienie w tych latach (lub ze wspomnianym wyżej opóźnieniem 1-2 lat) ruchów osuwiskowych (Braam i in. 1987, Krąpiec, Margielewski 2000).

Drewno reakcyjne to anomalia w budowie drewna występująca głównie w efekcie zwiększenia gęstości komórek drewna (ryc. 9B). W przypadku drzew nagonasiennych drewno reakcyjne pojawia się po ściskanej stronie pnia, zgodnie z kierunkiem pochylenia pnia, i jest nazywane drewnem kompresyjnym. Okrytonasienne wykształcają drewno reakcyjne po rozciąganej stronie pnia i nosi ono nazwę drewna tensyjnego (Timell 1986). Drewno reakcyjne pojawia się przy relatywnie dużym pochyleniu drzewa, około 5-7 (Kojs i in. 2012). Identyfikacja przyrostów rocznych, w których obrębie występuje drewno reakcyjne, pozwala na wskazanie lat, w których doszło do pochylenia drzewa wynikającego z osuwania (Shroder 1980).
Redukcje przyrostów rocznych występują w słojach drzew szczególnie silnie pochylonych, których systemy korzeniowe zostały przemieszczone w stosunku do ich pierwotnej pozycji (ryc. 9C). Korzenie tych drzew są często zrywane oraz wyciskane na powierzchnię. Utrudnia to transport wody i składników pokarmowych z korzeni do nadziemnej części drzewa, co skutkuje stresem zapisującym się w postaci tłumienia wzrostu drzewa. Przekłada się to na wykształcanie zredukowanych przyrostów rocznych drzew występujących po epizodzie osuwania (Lopez Saez i in. 2014). Obliczenie ilości przyrostów rocznych wykształconych po pierwszym roku, w którym zidentyfikowano redukcję przyrostów rocznych, pozwala wskazać rok, w którym doszło do epizodu osuwiskowego.

Analizy aktywności osuwania metodą dendrochronologiczną prowadzono, pobierając odwierty z drzew iglastych, głównie dlatego, że mają one bardziej czytelną strukturę drewna w porównaniu do drzew liściastych. Nie przyjęto dotąd jednolitej metodyki badań dendrochronologicznych do identyfikacji ruchów osuwiskowych. $\mathrm{W}$ niektórych pracach stosuje się analizę drewna reakcyjnego oraz redukcji przyrostów rocznych (Pánek i in. 2011, Lopez Saez i in. 2012, Stoffel i in. 2013), w innych badania dekoncentrycznego wzrostu drzew (Braam i in. 1987, Fantucci, McCord 1996, Corominas, Moya 1999, 2010, Krąpiec, Margielewski 2000, Stefanini 2004, Krąpiec $\mathrm{i}$ in. 2008).

Mimo stosunkowo długiej historii badań dendrochronologicznych osuwisk nie opracowano jak dotąd metody pozwalającej na określenie siły epizodu osuwiskowego w oparciu o różny poziom wykształcenia drewna reakcyjnego. Należy przy tym dodać, że poszczególne lata z drewnem reakcyjnym potrafią znacznie różnić się pod względem intensywności jego wykształcenia. Podobnie jest $z$ analizą redukcji przyrostów rocznych drzew. Redukcje te można podzielić ze względu na głębokość, np. na trzy klasy: silne, średnie i słabe (Malik, Owczarek 2009). Jednak nie ma ogólnie przyjętej metodyki w zakresie analizy redukcji przyrostów rocznych w celu identyfikacji osuwania. Analiza wzrostu dekoncentrycznego drzew pozwala na bardziej precyzyjną i obiektywną ocenę występowania epizodów osuwiskowych, głównie z uwagi na możliwość określenia liczbowo siły osuwania (Braam i in. 1987). Przyjmuje się, że różnica między szerokością tego samego przyrostu rocznego po stronie odstokowej i dostokowej określa siłę osuwania. Dodatkowo opracowano algorytm matematyczny pozwalający obliczać indeks dekoncetryczności, oparty na założeniu, że o aktywności osuwiskowej oraz jej sile informuje zmiana wskaźnika dekoncentryczności w kolejnych latach (Malik, Wistuba 2012).

Aby wyniki oceny aktywności osuwania metodą dendrochronologiczną były wiarygodne, powinny być dodatkowo pobierane próby $\mathrm{z}$ drzew rosnących na stabilnym stoku referencyjnym, położonym możliwie jak najbliżej stoku, na którym prowadzone są badania aktywności osuwiskowej. Stok referencyjny powinien być 
w miarę możliwości jak najbardziej podobny do badanego stoku osuwiskowego pod względem budowy geologicznej, nachylenia, składu gatunkowego lasu i wysokości nad poziomem morza (Shroder 1980, Malik, Wistuba 2012). Próby referencyjne są pobierane, ponieważ drzewa porastające stoki górskie są pochylane i, co za tym idzie, wykształcają przyrosty dekoncentryczne w wyniku oddziaływania różnych bodźców środowiskowych, np. wiatru, nacisku śniegu, a także innych niż osuwanie procesów geomorfologicznych, np. spełzywania. Bodźce te działają na drzewa w podobny sposób na stoku osuwiskowym i referencyjnym, dlatego można założyć podobny poziom dekoncentryczności wynikający z oddziaływania tych czynników środowiskowych. W metodyce badawczej powinno się traktować poziom dekoncentryczności wzrostu drzew na stoku referencyjnym jako podstawę do oceny aktywności stoku osuwiskowego. Przesłanką wskazującą na występowanie procesu osuwania jest sytuacja, gdy wskaźnik dekoncentryczności obliczony dla drzew rosnących na stoku osuwiskowym jest wyższy od wskaźnika policzonego dla stoku referencyjnego, czyli od tzw. progu referencyjnego (Wistuba i in. 2013). Stosowanie progów nie eliminuje całkowicie błędów związanych z interpretacją czynników wywołujących dekoncentryczny wzrost drzew, jednak skutecznie ogranicza możliwość ich popełnienia.

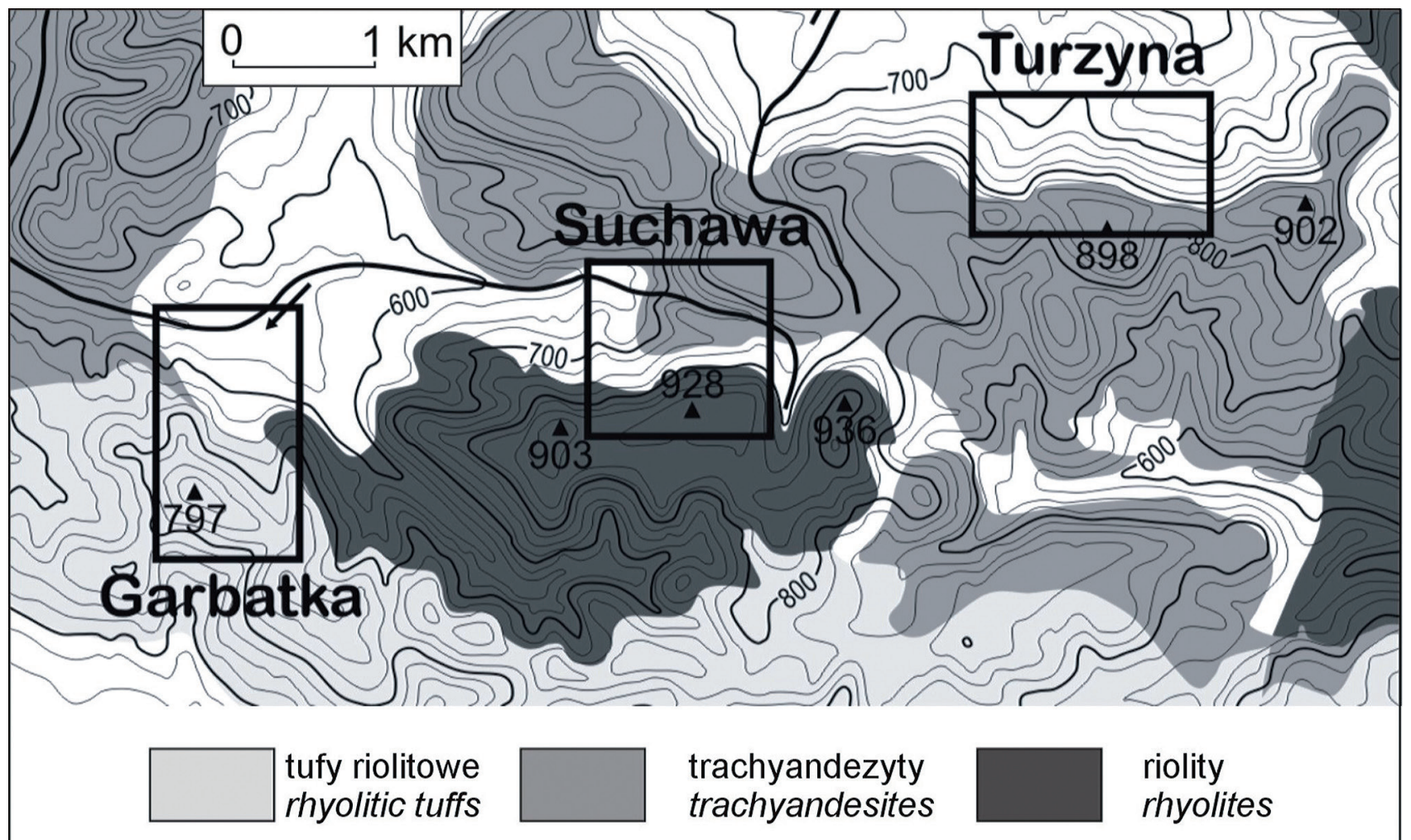

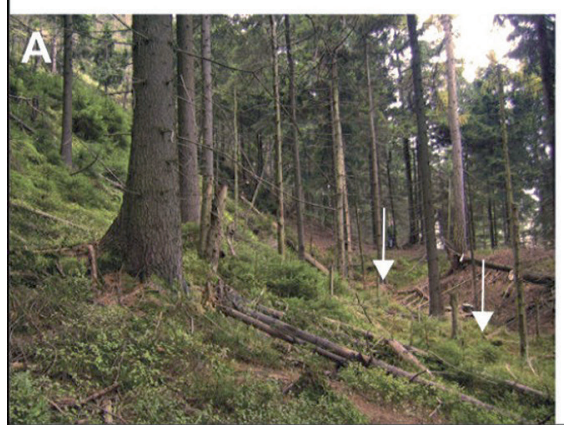

Turzyna

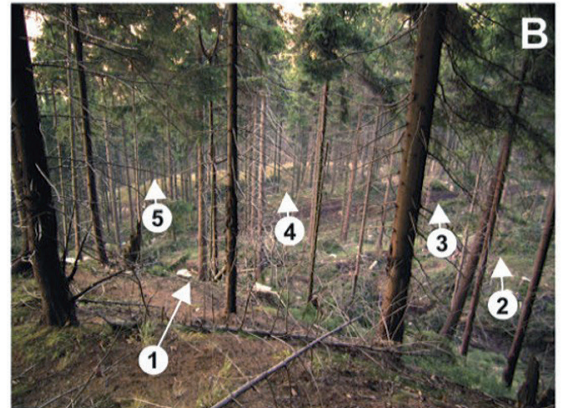

Suchawa

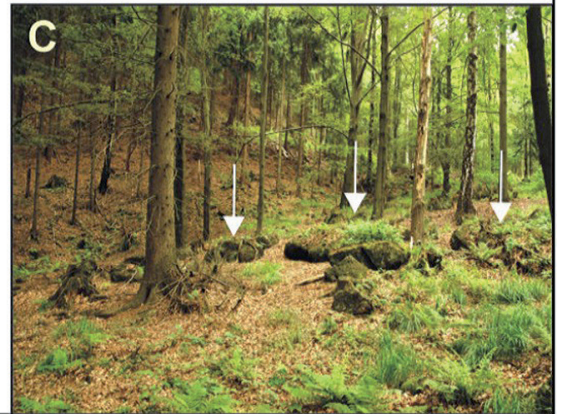

Garbatka

Ryc. 10. Położenie stanowisk, na których prowadzono badania dendrogeomorfologiczne

A - rów w górnej części stoku Turzyny (zaznaczony strzałkami), poniżej obniżonego pakietu przedstawionego na rycinie 3C, B - obniżone i zrotowane pakiety skalne na stoku Suchawy (zaznaczono strzałkami), C - bloki zatopione w materiale koluwialnym osuwiska spływowego w dolince pod Garbatką (zaznaczono strzałkami)

Fig. 10. Location of sites where dendrogeomorphological research was carried out

A - trench in the upper part of the Mt Turzyna slope (indicated by arrows), below the downthrown block shown on Fig. 3C, B - displaced and rotated landslide blocks on the Mt Suchawa slope (indicated by arrows), C- boulders partially sunk in flowslide colluvium in the valley floor below Mt Garbatka slope (indicated by arrows) 


\section{Zapis dendrochronologiczny aktywności osuwisk w Górach Kamiennych}

Pierwszą próbę zastosowania metody dendrochronologicznej do określenia współczesnej aktywności stoku podjęto w odniesieniu do stożków usypiskowych pod Suchawą i Włostową (Remisz i in. 2009, Malik i in. 2009, Migoń i in. 2010). Różnią się one stopniem porośnięcia przez roślinność, w tym drzewa, co było przesłanką wnioskowania o ich różnym wieku. Ponieważ oba usypiska znajdują się u podnóża skarp głównych i są zasilane przez odpadanie od ściany skalnej tworzącej skarpę główną, różnice w stabilności powierzchni stożków i stopniu ich skolonizowania mogą wskazywać na różny wiek powstania osuwisk. Badania dendrochronologiczne wykazały różnice w charakterze przyrostów drzew na obu stożkach, spójne z obrazem morfologicznym. Stożek pod Suchawą jest formą wysoce aktywną, podlegającą powolnemu grawitacyjnemu pełzaniu, natomiast usypisko pod Włostową jest bardziej ustabilizowane, a dostawa materiału ze ściany skalnej jest mniejsza (Remisz i in. 2009, Migoń i in. 2010). Rozszerzone analizy przyrostów rocznych drzew porastających usypiska pod Suchawą potwierdziły niemal nieprzerwane przemieszczenia gruzu na stoku (Remisz, Bijak 2012), co wprawdzie nie datuje zdarzenia osuwiskowego, ale jest cenną przesłanką do wnioskowania o jego względnie młodym wieku. Wniosek ten jest spójny z wynikami badań wykształcenia pokrywy glebowej w tej części Gór Suchych (Kacprzak i in. 2013).

Kolejną próbę określenia aktywności osuwisk metodami dendrochronologicznymi podjęto w odniesieniu do właściwych koluwiów osuwiskowych, w obrębie trzech różniących się morfologią i genezą zespołów form osuwiskowych (Malik i in., w recenzji). Opróbowano świerki rosnące $\mathrm{w}$ obrębie zwartego pakietu osuwiskowego na Turzynie, zrotowanych bloków osuwiska pod Suchawą (na wschód od Czerwonych Skałek i omawianego wyżej osypiska) i wypełniającego dno doliny jęzora koluwialnego pod Garbatką (ryc. 10). Na wszystkich stanowiskach pnie wielu drzew były pochylone, najczęściej w kierunku zgodnym ze spadkiem stoków. Opróbowano 13 drzew pod Turzyną, 36 drzew na stokach Suchawy i $21 \mathrm{w}$ dolinie pod Garbatką. Do określenia aktywności osuwiskowej wykorzystano indeks dekoncentryczności obliczany według wzorów zaproponowanych przez Wistube $\mathrm{i}$ in. (2013). Pobrano także próby z 30 drzew rosnących na 3 stanowiskach referencyjnych (po 10 prób dla każdego stanowiska).

Porównanie wartości indeksu dekoncentryczności na stokach osuwiskowych i na stokach referencyjnych pozwoliło na wyznaczenie progów dekoncentryczności. Wynoszą one dla Turzyny $>58,96 \%$ (próg dla dekoncentryczności dostokowej) oraz $<-64,89 \%$ (dla dekoncentryczności odstokowej), zaś dla Suchawy i Garbatki $>59,39 \%$ i $<-64,35 \%$ oraz $>56,52 \%$ i $<-51,40 \%$. Przez analizę zmienności indeksów dla okresu 1940-2011 wykryto aż 523 sygnały osuwania zapisane w postaci skoku dekoncentryczności wzrostu drzew (ryc. 11). Materiał

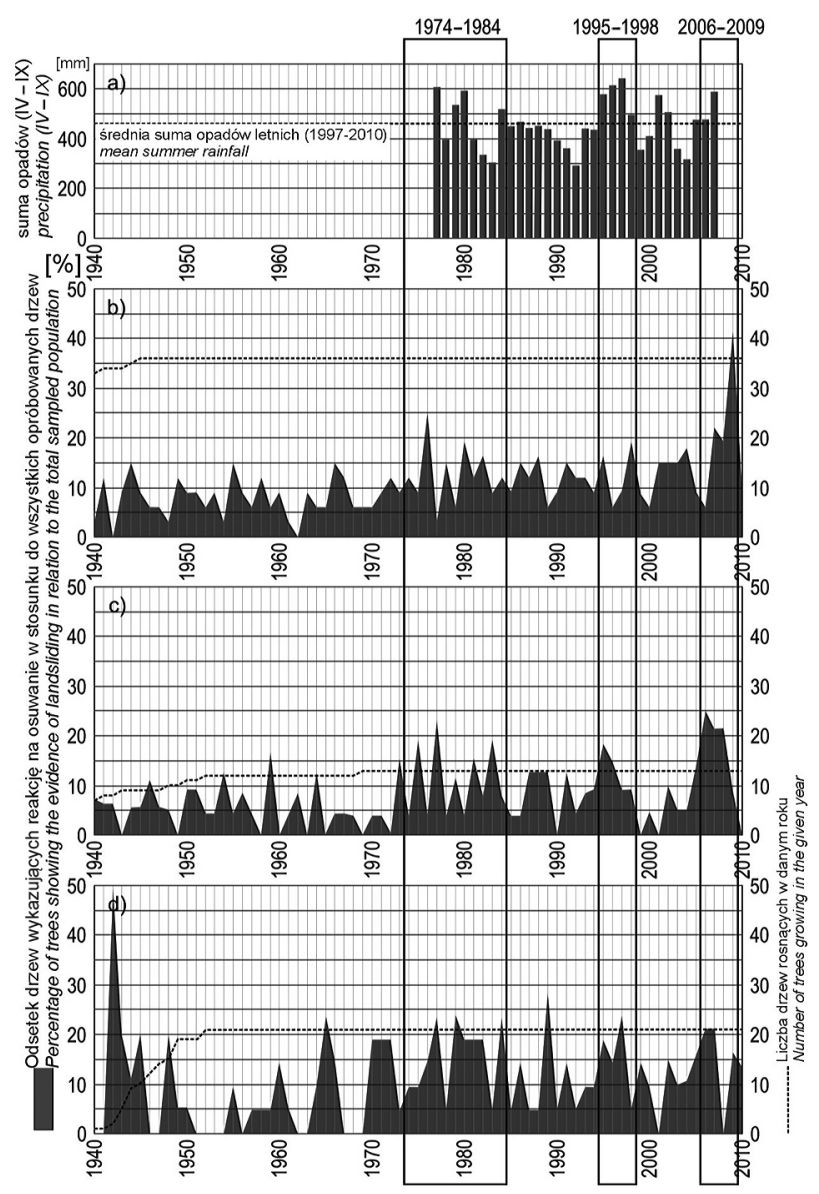

Ryc. 11. Dendrochronologiczna rekonstrukcja aktywności osuwisk na Suchawie, Turzynie i Garbatce

a) sumy opadów dla połowy roku (kwiecień-wrzesień) i odsetek drzew reagujących na osuwanie w stosunku do wszystkich pobranych prób na stanowiskach, b) Suchawa, c) Turzyna, d) Garbatka

Fig. 11. Dendrochronological reconstruction of landslide activity at Mt Suchawa, Mt Turzyna, and in the valley below Mt Garbatka

a) precipitation totals of the summer half year (April-September) compared with percentage of trees showing reaction to landsliding in the sampled population of trees, b) Suchawa landslide, c) Turzyna landslide, d) Garbatka landslide

jest przemieszczany praktycznie corocznie, ale na stosunkowo niewielką odległość. Poszczególne epizody ruchu wystąpiły mniej więcej synchronicznie na badanych stokach, jednak ze zróżnicowaną siłą (ryc. 11). Największą aktywność odnotowano w latach 1974-1984, 1995-1998 i 2006-2009. Zauważono, że na stokach Suchawy dochodzi do propagacji ruchu, który często pojawia się najpierw w dolnej części stoku, a w kolejnych latach występuje w jego coraz wyższych partiach.

Korelacja wysokich opadów w okresie wegetacyjnym z epizodami osuwiskowymi jest bardzo niewielka dla głębokich osuwisk na Suchawie i Turzynie. Współczynnik korelacji liniowej Pearsona wynosi tu odpowiednio $-0,03$ i 0,04 . Korelacja jest znacznie lepsza dla osuwiska spływowego pod Garbatką, gdzie wynosi ona 0,53 . Może to odzwierciedlać zarówno różnicę w rodzaju skał występujących na stanowiskach, jak i typ osuwiska. Do- 
bra przepuszczalność spękanych riolitów i trachyandezytów budujących wzniesienia Suchawy i Turzyny może powodować brak bezpośredniej reakcji stoku na opady. W przypadku osuwiska na Garbatce różnofrakcyjny materiał w obrębie jęzora koluwialnego może przemieszczać się w dół stoku już w czasie epizodu opadowego. Jednoznaczna interpretacja zapisu dendrochronologicznego nie jest jednak łatwa. W odniesieniu do osuwiska pod Garbatką zaproponowano także alternatywną interpretację, zgodnie z którą rejestrowane deformacje drzew mogą być reakcją na przebudowę struktury jęzora koluwialnego wskutek procesów sufozyjnych w obrębie mało zwięzłego, różnofrakcyjnego materiału (Migoń i in. 2014b).

Wyniki badań dendrochronologicznych wskazują, że badane osuwiska można zakwalifikować do grupy powolnych osuwisk (ang. slow-moving landslides). Takie niewielkie ruchy osuwiskowe mogą wyprzedzać wystąpienie katastrofalnych osuwisk, co miało miejsce np. na stoku góry Prusów w gminie Milówka (Beskid Żywiecki) (Wistuba i in., w druku).

\section{Ocena zagrożeń i ryzyka}

Zagrożenie i ryzyko nie są synonimami. Zagrożenie osuwiskami należy rozumieć jako zjawisko wywołane działaniem sił natury (niekiedy w konsekwencji działań człowieka), powodujące zmniejszenie lub zanik poczucia bezpieczeństwa. Ryzyko jest natomiast wskaźnikiem stanów lub zdarzeń, które mogą powodować straty (Thywissen 2006). W ujęciu analitycznym przedstawia się je najczęściej równaniem:

$$
R=H \cdot V
$$

gdzie:

$R$ - ryzyko (ang. risk),

$H$-zagrożenie (ang. hazard),

$V$ - podatność na straty (ang. vulnerability).

W dotychczasowej literaturze pojawiają się jedynie wzmianki o możliwych zagrożeniach wynikających z faktu występowania ruchów masowych w Górach Kamiennych, natomiast pogłębionych analiz zagrożeń i ryzyka nie prowadzono. Kasprzak i Traczyk (2012) podjęli się oceny uwarunkowań procesów osuwiskowych w skali regionu na podstawie pierwotnych i wtórnych parametrów geomorfometrycznych, tj. nachylenia, energii rzeźby (przewyższenia w zadanym otoczeniu, zadano $250 \mathrm{~m}$ ) i topograficznego indeksu uwilgotnienia (ang. Topographic Wetness Index - TWI). Wynik modelowania zestawiony $\mathrm{z}$ faktycznym rozmieszczeniem osuwisk według stanu rozpoznania kartograficznego na rok 2010 pokazał, że spośród zastosowanych parametrów (reprezentujących czynniki pasywne) w największym stopniu skorelowane z podatnością stoków na ruchy osuwiskowe są nachylenie stoków oraz energia rzeźby. Mniej istotne znaczenie odgrywa parametr TWI, określający stosunki wodne jedynie na podstawie akumulacji teoretycznego spływu po powierzchni stokowej. Do prawidłowego określenia faktycznego oddziaływania czynnika hydrologicznego i hydrogeologicznego potrzebne są informacje na temat pojemności wodnej ośrodków skalnych i rozmieszczenia wysięków/wypływów wód podziemnych.

$\mathrm{Na}$ problem zagrożeń związanych z procesami osuwiskowymi w Górach Kamiennych należy spojrzeć w dwóch kontekstach: stanu wiedzy o wieku osuwisk oraz stanu zagospodarowania obszaru. Wyniki dotychczasowych badań prowadzą do następujących uogólnień odnośnie do ram czasowych wielkoskalowych ruchów masowych w regionie:

- różna wyrazistość form rzeźby osuwiskowej wskazuje na różny wiek osuwisk, który prawdopodobnie waha się w szerokich granicach, od plejstocenu po czasy bliskie współczesności;

- powyższa uwaga znajduje potwierdzenie w wynikach badań pokrywy glebowej na osuwiskach, a niski stopień wykształcenia gleb wskazuje, że część osuwisk powstała lub była reaktywowana w holocenie, być może nawet w późnym holocenie; do podobnych wniosków prowadzą wyniki datowania radiowęglem materiału organicznego pobranego ze spągowych partii osadów z jeziorek osuwiskowych oraz ocena stanu morfodynamicznego stożków usypiskowych;

- brak danych historycznych o aktywności osuwisk, co pozwala przypuszczać, że w stosunkowo gęsto zaludnionym regionie wałbrzyskim, zindustrializowanym już pod koniec XVIII w. (Wójcik 2011) w ostatnich 200 latach nie miały miejsce żadne większe przypadki niestabilności stoku;

- sygnały dendrochronologiczne wskazują na powolne, ale niesystematyczne przemieszczenia grawitacyjne w obrębie kilku badanych osuwisk;

- niektóre cechy rzeźby stoków osuwiskowych (szczeliny z rozciągania - Lesista Wielka, nieznacznie osunięte zwarte bloki skalne - Turzyna) mogą być interpretowane jako charakterystyczne dla wstępnych bądź inicjalnych przemieszczeń, poprzedzających ruchy osuwiskowe na większą skalę; hipotezę taką wzmacnia fakt obecności w bezpośrednim sąsiedztwie osuwisk o ukształtowanej rzeźbie, ze skalistymi skarpami głównymi, pakietami osuwiskowymi i koluwiami w najniższej części stoku.

Podsumowując, jakkolwiek w czasach historycznych nie odnotowano $\mathrm{w}$ analizowanym regionie ruchów osuwiskowych, w zbliżonych warunkach środowiskowych we wcześniejszych fazach holocenu część stoków Gór Kamiennych niewątpliwie wykazywała niestabilność. Osuwiska należy zatem uznać za element składowy także współczesnego systemu morfogenetycznego, aczkolwiek o niskiej częstotliwości i prawdopodobieństwie występowania.

Ocena stanu zagrożenia z punktu widzenia zagospodarowania i użytkowania terenu prowadzi do konstatacji, że przy obecnym stanie tego zagospodarowania należy je ocenić jako bardzo niskie. Osuwiska są niemal w całości zlokalizowane na obszarach leśnych, jedynie w kil- 
ku przypadkach jęzory osuwiskowe sięgnęły den dolin i obszarów zabudowanych. Taka sytuacja ma miejsce w przypadku osuwiska pod Garbatką, na którego rozmytym jęzorze posadowiono kilka budynków w Sokołowsku. To osuwisko jest jednak z pewnością wieku przedholoceńskiego (Kasprzak i in. 2014, Migoń i in. 2014b). Jedynymi elementami infrastruktury, które mogłyby ulec uszkodzeniu w bezpośredni sposób, są drogi leśne, więc ryzyko osuwiskowe można ocenić jako marginalne. Poważniejszym problemem mogłoby być przegrodzenie przez jęzor osuwiskowy dna doliny i czasowe spiętrzenie wód potoku, po którym może dojść do nagłego spłynięcia wód i wezbrania poniżej. Układ form rzeźby wskazuje, że w Górach Kamiennych taka sytuacja miała miejsce przynajmniej dwukrotnie: w dolinie Sokołowca, przegrodzonej przez koluwia osuwiska, które zeszło spod Włostowej, i w bezimiennej dolince na północ od Jeleńca Małego.

\section{Podsumowanie}

W porównaniu z Karpatami fliszowymi procesy osuwiskowe w Sudetach są postrzegane jako zagrożenie znacznie niższej rangi, o czym może świadczyć chociażby plan przeprowadzenia badań $\mathrm{w}$ regionie sudeckim dopiero w dalszych etapach realizacji programu SOPO (Grabowski $\mathrm{i}$ in. 2008). Takie podejście ma pewne uzasadnienie, gdyż rzeczywiście w okresie historycznym osuwisk w Sudetach powstało niewiele (Parzóch, Migoń 2010) i były one związane z wyjątkowymi sytuacjami meteorologicznymi, takimi jak intensywne opady deszczu w lipcu 1997 r. i 1998 r. (Żurawek 1999). Generalnie miały one także niewielkie rozmiary. W tym kontekście wyraźnie ukazuje się aplikacyjny wymiar badań podstawowych w zakresie geomorfologii, polegający na rozpoznaniu ewentualnych zagrożeń związanych z procesami pojawiającymi się rzadko i w specyficznych miejscach, a dokumentowanych reliktowymi formami rzeźby terenu.

Zasadne jest zatem postawienie trzech, kolejno wynikających z siebie pytań badawczych. Po pierwsze, czy w Sudetach występują elementy rzeźby osuwiskowej z okresu wcześniejszego niż historyczny? Po drugie, jeśli tak, to w jakich warunkach środowiskowych osuwiska te powstawały i czy są przesłanki do wnioskowania o ich holoceńskim wieku? Po trzecie, czy te reliktowe osuwiska są obecnie w stanie pełnej stabilizacji? Doświadczenia z Gór Kamiennych pokazują, że odpowiedzi na te pytania mogą być uzyskane w ramach interdyscyplinarnych badań, łączących różne dziedziny nauk przyrodniczych. Identyfikacji rzeźby osuwiskowej można dokonać przez klasyczne kartowanie geomorfologiczne, zwłaszcza gdy będzie ono wspomagane przez analizę cyfrowego modelu wysokości o dużej rozdzielczości (LiDAR), dostępnego obecnie dla całych Sudetów. Badania gleb, a w szczególności stopnia zaawansowania ich rozwoju, pozwalają na wskazanie powierzchni, dla których czas trwania pedogenezy jest krótszy niż długość całego holocenu, co jest ważną przesłanką wskazującą na holoceński wiek osu- wisk (dotyczy to zwłaszcza osuwisk spływowych). Z kolei dzięki badaniom przyrostów rocznych drzew możliwe jest wyróżnienie miejsc, gdzie stoki są niestabilne, co może wskazywać na permanentne, powolne osuwanie. W Górach Kamiennych na wszystkie trzy wyżej postawione pytania uzyskano odpowiedź twierdzącą, choć status morfodynamiczny rozpoznanych osuwisk jest zróżnicowany. Obok form ewidentnie reliktowych, o silnie zatartej rzeźbie, występują formy o uderzająco „świeżej” morfologii, z licznymi oznakami współczesnej aktywizacji ruchów masowych.

Przedstawiony przykład wielostronnego podejścia do problemu ukazuje równocześnie wagę badań geomorfologicznych, gdyż identyfikacja form nabiera kluczowego znaczenia i pozwala odpowiednio zaplanować dalsze badania gleboznawcze, dendrochronologiczne czy ewentualny monitoring wybranych obiektów w przyszłości. Największym wyzwaniem na przyszłość jest natomiast odpowiedź na pytanie, w jakich warunkach może dojść do ponownego ożywienia osuwisk, które obecnie są stabilne. Wielowymiarowe modelowanie podatności stoków na osuwanie będzie kolejnym krokiem w rozpoznaniu zagrożeń związanych z osuwiskami w Sudetach.

\section{Podziękowania}

Badania osuwisk w Górach Kamiennych były prowadzone w ramach projektów MNiSW N N306 312636 i N N306 027 737, a następnie w ramach działalności statutowej Instytutu Geografii i Rozwoju Regionalnego Uniwersytetu Wrocławskiego (1015/S/2013-2014). Dane LiDAR zostały pozyskane z Centralnego Ośrodka Dokumentacji Geodezyjnej i Kartograficznej w Warszawie. Autorzy składają serdeczne podziękowania wszystkim osobom, które uczestniczyły w różnych etapach realizacji tych projektów. W szczególności byli to Jan Hradecký, Łukasz Musielok, Piotr Owczarek, Tomaš Pánek, Łukasz Pawlik, Joanna Remisz, Łukasz Wielgos i Małgorzata Wistuba. Podziękowania kierujemy także pod adresem Nadleśnictwa Wałbrzych za udzielenie zgody na prowadzenie badań terenowych oraz Ekumenicznego Ośrodka Spotkań Integracyjnych w Sokołowsku (Anna i Rafał Dzimira) za wsparcie logistyczne w trakcie badań terenowych i nieustanną życzliwość. Dziękujemy także trzem recenzentom za konstruktywne wskazówki, które przyczyniły się do udoskonalenia pierwotnego tekstu artykułu.

\section{Literatura}

Alestalo J., 1971. Dendrochronological interpretation of geomorphic processes. Fennia 105: 1-140.

Awdankiewicz M., 1999. Volcanism in a late Variscan intramontane trough: Carboniferous and Permian volcanic centres of the Intra-Sudetic Basin, SW Poland. Geologia Sudetica 32: 13-47.

Berg G., 1925. Geologische Karte von Preussen 1:25 000. Blatt Waldenburg.

Berg G., Dathe E., Zimmermann E., 1910. Geologische Karte von Preussen 1:25 000. Blatt Friedland i. Schl. 
Bibus E., Kallinich J., Terhorst B., 2001. Dating methods for mass movements studied by the MABIS Project. Zeitschrift f. Geomorphologie, Suppl.-Bd. 125: 153-162.

Birkeland P.W., 1999. Soils and Geomorphology. Oxford University Press, New York.

Bober L., 1984. Rejony osuwiskowe w polskich Karpatach fliszowych i ich związek z budową geologiczną regionu. Biuletyn Instytutu Geologicznego 340: 115-162.

Bossowski A., Cymerman Z., Grocholski A., Ihnatowicz A. 1994. Szczegółowa Mapa Geologiczna Sudetów 1:25 000. Arkusz Jedlina Zdrój. Państwowy Instytut Geologiczny, Warszawa.

Bossowski A., Cymerman Z., Grocholski A., Ihnatowicz A. 1995. Objaśnienia do Szczegółowej Mapy Geologicznej Sudetów. Arkusz Jedlina Zdrój. Państwowy Instytut Geologiczny, Warszawa.

Bossowski A., Ihnatowicz A., 1994. Palaeogeography of the uppermost Carboniferous and lowermost Permian deposits in NE part of the Intra-Sudetic Depression. Geological Quarterly 38: 709-726.

Braam R.R., Weiss E.E.J., Burrough P.A., 1987. Spatial and temporal analysis of mass movement using dendrochronology. Catena Supplement 9: 573-584.

Cooke R.U., Doornkamp J.C., 1990. Geomorphology in Environmental Management ( $2^{\text {nd }}$ ed.). Oxford University Press, Oxford.

Corominas J., Moya J., 1999. Reconstructing recent landslides activity in relation to rainfall in the Llobregat River basin, Eastern Pyrenees, Spain. Geomorphology 30: 79-93.

Corominas J., Moya J., 2010. Contribution of dendrochronology to the determination of magnitude-frequency relationships for landslides. Geomorphology 124: 137-149.

Crozier M.J., 1973. Techniques for the morphometric analysis of landslips. Zeitschrift für Geomorphologie 17: 78-101.

Dathe E., Berg G., 1926. Erläuterungen zur Geologischen Karte von Preußen und benachbarten deutschen Ländern. Lieferung 145. Blatt Waldenburg i. Schl., Berlin (2. Aufl.)

Dathe E., Zimmermann E., Berg G., 1910. Erläuterungen zur Geologischen Karte von Preußen und benachbarten Bundesstaaten. Lieferung 145. Blatt Friedland i. Schl., Berlin.

Dewitte O., Demoulin A., 2005. Morphometry and kinematics of landslides inferred from precise DTMs in West Belgium. Natural Hazards and Earth Systems Science 5: 259-265.

Dikau R., Brunsden D., Schrott L., Ibsen M.-L. (red.), 1995. Landslide Recognition. Wiley, Chichester.

Don J., Jerzykiewicz T., Teisseyre A.K., Wojciechowska I., 1979. Szczegółowa Mapa Geologiczna Sudetów. Arkusz Lubawka. Państwowy Instytut Geologiczny, Warszawa.

Dudziak T., 1984. Szczeliny wiatrowe na Lesistej Wielkiej. Karkonosze, Materiały Krajoznawcze 1: 5-11. SKPS, Wrocław.

Fantucci R., McCord A., 1996. Reconstruction of landslide dynamic with dendrochronological methods. Dendrochronologia 13: 1-22.

Grabowski D., Marciniec P., Mrozek T., Nescieruk P., Rączkowski W., Wójcik A., Zimnal Z., 2008. Instrukcja opracowania Mapy osuwisk i terenów zagrożonych ruchami masowymi w skali 1 : 10 000. Państwowy Instytut Geologiczny, Warszawa.

Griffiths J.S., Whitworth M., 2012. Engineering geomorphology of landslides. In: J.J. Clague, D. Stead (red.), Landslides: Types, Mechanisms and Modeling. Cambridge University Press, Cambridge: 172-186.

Grocholski A., 1971. Szczegółowa Mapa Geologiczna Sudetów. Arkusz Mieroszów. Państwowy Instytut Geologiczny, Warszawa.

Grocholski A., 1972. Ślady osuwisk na stokach Lesistej Wielkiej w Górach Kamiennych. Polskie Towarzystwo Miłośników Nauk o Ziemi, Koło Górnicze w Gorcach, Biuletyn Informacyjny 11: 9-14.

Grocholski A., 1973. Objaśnienia do Szczegółowej Mapy Geologicznej Sudetów. Arkusz Mieroszów. Państwowy Instytut Geologiczny, Warszawa.

Hattanji T., Moriwaki H., 2009. Morphometric analysis of relic landslides using detailed landslide distribution maps: Implications for forecasting travel distance of future landslides. Geomorphology 103: 447-454.

Hradecký J., Pánek T., Švarc J., 2008. Geoecological imprints of mass movements on habitats - the case studies from the Czech part of the Western Carpathians (Czech Republic). Moravian Geographical Reports 16(2): 25-35.

Hungr O., Leroueil J., Picarelli L., 2014. The Varnes classification of landslide types, an update. Landslides 11: 167-194.
Instrukcja opracowania mapy osuwisk i terenów zagrożonych ruchami masowymi w skali 1:10 000, 2008. Państwowy Instytut Geologiczny, Warszawa.

Jońca E., 1987. Projektowany rezerwat przyrody nieożywionej Jeleniec w Górach Suchych w Sudetach Środkowych. Chrońmy Przyrodę Ojczystą 43(2): 61-68.

Kacprzak A., Migoń P., 2013. Using soil properties as a tool to differentiate landslide generations and constrain their ages - Rogowiec landslide, Sudetes (SW Poland). Geophysical Research Abstracts 15, EGU2013-10132.

Kacprzak A., Migoń P., Musielok Ł., 2013. Using soils as indicators of past slope instability in forested terrain, Kamienne Mts, SW Poland. Geomorphology 194: 65-75.

Kacprzak A., Musielok Ł., Skiba S., 2011. Zastosowanie nowej systematyki gleb Polski w kartowaniu pokrywy glebowej wybranego fragmentu Sudetów (Góry Kamienne). W: S. Gonet, P. Hulisz, M. Markiewicz (red.), Gleba-człowiek-środowisko. Mat. Konfer. 28. Kongresu Gleboznawczego, Toruń, 5-10 września 2011 r.: 70.

Kasprzak M., Biernacka J., Chomicz J., Michniewicz A., 2014. Morfologia i osady małych dolin denudacyjnych w masywie Garbatki (Góry Suche). Przyroda Sudetów 17: 199-212.

Kasprzak M., Traczyk A., 2012. Uwarunkowania rozwoju osuwisk w środkowej części Gór Kamiennych (Sudety). Landform Analysis 20: $65-77$.

Kasprzak M., Traczyk A., 2014. LiDAR and 2D Electrical Resistivity Tomography as a Supplement of Geomorphological Investigations in Urban Areas: a Case Study from the City of Wrocław (SW Poland). Pure and Applied Geophysics 171, 6: 835-855.

Kleber A., 1997. Cover-beds as soil parent materials in mid-latitude regions. Catena 30: 197-213.

Knapik R., Jała Z., Sobczyk A., Migoń P., Aleksandrowski P., Szuszkiewicz A., Krąpiec M., Madej S., Krakowski K., 2009. Inwentaryzacja i waloryzacja geostanowisk Karkonoskiego Parku Narodowego i jego otuliny oraz wykonanie mapy geologicznej tego obszaru. Archiwum Karkonoskiego Parku Narodowego.

Kojs P., Malik I., Wistuba M., 2012. Mechanizmy wzrostu ekscentrycznego i formowania się drewna reakcyjnego w kontekście badań dendrogeomorfologicznych - wprowadzenie do nowej hipotezy. Studia i Materiały Centrum Edukacji Przyrodniczo-Leśnej 1(30): 147-156.

Krąpiec M., Danek M., Gil E., Kłusek M., Rączkowski W., Zabuski L., 2008. Monitoring dendrogeomorfologiczny osuwisk w Beskidzie Niskim. Prace Komisji Paleogeografii Czwartorzędu PAU 6: 173-184.

Krąpiec M., Margielewski W., 2000. Analiza dendrogeomorfologiczna ruchów masowych na obszarze polskich Karpat fliszowych. Geologia Kwartalnik AGH 26(2): 141-171.

Krzemień K., Libelt P., Mączka T., 1995. Geomorphological conditions of the timberline in the Western Tatra Mountains. Zeszyty Naukowe UJ, Prace Geograficzne 98: 153-170.

Lopez Saez J., Corona C., Stoffel M., Astrade L., Berger F., Malet J.P., 2012. Dendrogeomorphic reconstruction of past landslide reactivation with seasonal precision: the Bois Noir landslide, southeast French Alps. Landslides 9: 189-203.

Lopez Saez J., Corona C., Stoffel M., Berger F., 2014. Tree roots record precursor signals of landslide activity. Géomorphologie: Processus, Relief, Environnement 2/14: 159-174.

Malik I., Owczarek P., 2009. Dendrochronological records of debris flow and avalanche activity in a mid-mountain forest zone (Eastern Sudetes - Central Europe). Geochronometria 34: 57-66.

Malik I., Owczarek P., Migoń P., 2009. Rock fall as a source of sediment in the forested mid-mountain zone in the Kamienne Mts (Sudetes - SW Poland). W: R.J. Kaczka, I. Malik, P. Owczarek, H. Gärtner, I. Heinrich, G. Helle, G. Schleser (red.), TRACE. Tree Rings in Archaeology, Climatology and Ecology. Vol. 7. Proceedings of the Dendrosymposium 2008, April 27th-30th, 2008 in Zakopane, Poland, Scientfic Technical Report STR09/03 series, Helmholtz-Zentrum Potsdam: 176-180.

Malik I., Wistuba M., 2012. Dendrochronological methods for reconstructing mass movements - An example of landslide activity analysis using tree-ring eccentricity. Geochronometria 39: 180-196.

Malik I., Wistuba M., Migoń P., Fajer M., Chochół K., Activity of slow-moving landslides recorded in eccentric tree rings of Norway spruce trees (Picea abies Karst.) - an example from Kamienne Mts. (Sudetes Mts., Central Europe). Géomorphologie (artykuł w recenzji). 
Margielewski W., 2004. Typy przemieszczeń grawitacyjnych mas skalnych w obrębie form osuwiskowych polskich Karpat fliszowych. Przegląd Geologiczny 52: 603-614.

Margielewski W., 2009. Problematyka osuwisk strukturalnych w Karpatach fliszowych w świetle zunifikowanych kryteriów klasyfikacji ruchów masowych - przegląd krytyczny. Przegląd Geologiczny 57: 905-917.

Margielewski W., Święchowicz J., Starkel L., Łajczak A., Pietrzak M., 2008. Współczesna ewolucja rzeźby Karpat fliszowych. W: L. Starkel, A. Kotarba, A. Kostrzewski, K. Krzemień (red.), Współczesne przemiany rzeźby Polski. Instytut Geografii i Gospodarki Przestrzennej, Uniwersytet Jagielloński, Kraków: 57-133.

Migoń P., 2008. Współczesna ewolucja rzeźby Sudetów i ich Przedgórza. W: L. Starkel, A. Kotarba, A. Kostrzewski, K. Krzemień (red.), Współczesne przemiany rzeźby Polski. Instytut Geografii i Gospodarki Przestrzennej, Uniwersytet Jagielloński, Kraków: 135-163.

Migoń P., 2010. Nowe dane do poznania rzeźby osuwiskowej Gór Kamiennych. Przyroda Sudetów 13: 215-224.

Migoń P., Jancewicz K., Kasprzak M., 2014a. Zasięg obszarów objętych osuwiskami w Górach Kamiennych (Sudety Środkowe) - porównanie map geologicznych i cyfrowego modelu wysokości z danych LiDAR. Przegląd Geologiczny 64: 463-471.

Migoń P., Kacprzak A., 2014. Lateral variability of hillslope regolith and soils and implications for the interpretation of Pleistocene environments. Geomorphology 221: 69-82.

Migoń P., Kacprzak A., Malik I., Kasprzak M., Owczarek P., Wistuba M., Pánek T., 2014b. Geomorphological, pedological and dendrochronological signatures of a relict landslide terrain, Mt Garbatka (Kamienne Mts), SW Poland. Geomorphology 219: 213-231.

Migoń P., Kasprzak M., Traczyk A., 2013. How high-resolution DEM based on airborne LiDAR helped to reinterpret landforms - examples from the Sudetes, SW Poland. Landform Analysis 22: 89-101.

Migoń P., Parzóch K., 2008. Spływy gruzowe w Sudetach. Przegląd Geograficzny 80: 385-401.

Migoń P., Pánek T., Malik I., Hradecký J., Owczarek P., Šilhán K., 2010. Complex landslide terrain in the Kamienne Mountains, Middle Sudetes, SW Poland. Geomorphology 124: 200-214.

Migoń P., Placek A., 2014. Litologiczno-strukturalne uwarunkowania rzeźby Sudetów. Przegląd Geologiczny 64: 36-43.

Musielok Ł., Kacprzak A., 2012. Application of the WRB and USDA Soil Taxonomy in soil mapping on the example of an area transformed by mass wasting activity in Góry Kamienne (Sudetes, SW Poland). W: EUROSOIL 2012. Book of abstracts: 956.

Nowakowski A., 1968. Wulkanity permskie Gór Suchych w niecce śródsudeckiej. Geologia Sudetica 4: 299-408.

Pánek T., Šilhán K., Tabořík P., Hradecký J., Smolková V., Lenart J., Brázdil R., Kašičková L., Pazdur A., 2011. Catastrophic slope failure and its origins: case study of the May 2010 Girová Mountain long-runout rockslide (Czech Republic). Geomorphology 130: 352-364.

Parzóch K., Migoń P., 2010. Zdarzenia ekstremalne w systemie stokowym - grawitacyjne ruchy masowe i erozja gleb. W: P. Migoń (red.), Wyjątkowe zdarzenia przyrodnicze na Dolnym Śląsku i ich skutki. Rozprawy Naukowe Instytutu Geografii i Rozwoju Regionalnego Uniwersytetu Wrocławskiego 14: 205-239.

Placek A., 2011. Rzeźba strukturalna Sudetów w świetle wyników pomiarów wytrzymałości skał i analiz numerycznego modelu wysokości. Rozprawy Naukowe Instytutu Geografii i Rozwoju Regionalnego Uniwersytetu Wrocławskiego 16: 1-190.

Pulinowa M.Z., 1972. Procesy osuwiskowe w środowisku sztucznym i naturalnym. Dokumentacja Geograficzna IG PAN 4: 1-112.

Pulinowa M.Z., Mazur R., 1971. Stare osuwisko we wsi Grzmiąca w Sudetach. Wszechświat 7-8: 200-202.

Raport dostawy, ISOK - Informatyczny System Osłony Kraju przed nadzwyczajnymi zagrożeniami, Część nr 3, Etap nr 03, 2011-09-12.

Rączkowski W., Mrozek T., 2002. Activating of landsliding in the Polish Flysch Carpathians by the end of the 20th century. Studia Geomorphologica Carpatho-Balcanica 36: 91-111.

Remisz J., 2012. Morfodynamika stoków usypiskowych Ostrzycy i Kalwarii k. Barda (Sudety). Materiały CEPL w Rogowie 14, 1 (30): $176-184$.

Remisz J., Bijak S., 2012. Dendrochronologiczny zapis aktywności stoków usypiskowych Suchawy i Kruczej Skały (Sudety Środkowe). Przyroda Sudetów 15: 209-218.
Remisz J., Migoń P., Malik I., Owczarek P., 2009. Stoki usypiskowe w polskiej części Sudetów - rozmieszczenie i wiek. W: A. Kostrzewski, R. Paluszkiewicz (red.), Geneza, litologia i stratygrafia utworów czwartorzędowych. T. V. UAM, Seria Geografia 88: 447-465.

Schaetzl R., Anderson S., 2005. Soils: Genesis and Geomorphology. Cambridge University Press, Cambridge.

Semmel A., Terhorst B., 2010. The concept of the Pleistocene periglacial cover beds in central Europe: A review. Quaternary International 222: $120-128$.

Shroder Jr. J.F., 1980. Dendrogeomorphology: review and new techniques of tree-ring dating. Progress in Physical Geography 4: 161-188.

Smolová I., 2002. Geomorfologická analýza reliéfu Javořích hor. W: Geomorfologický sborník 1. Sborník př́spěvků z mezinárodního semináře Stav geomorfologických výzkumů v roce 2002. Masarykova univerzita, Brno: 127-131.

Stefanini M.C., 2004. Spatio-temporal analysis of a complex landslide in the Northern Apennines (Italy) by means of dendrochronology. Geomorphology 63: 191-202.

Stoffel M., Butler D.R., Corona C., 2013. Mass movements and tree rings: A guide to dendrogeomorphic field sampling and dating. Geomorphology 200: 106-120.

Synowiec G., 2003a. Formy osuwiskowe w Górach Kamiennych. Przegląd Geologiczny 51: 59-65.

Synowiec G., 2003b. Structural landslides in the Kamienne Gory Mts., Sudetes, SW Poland. W: J. Rybař, J. Stemberk, G. Wagner (red.), Landslides. Swets \& Zeitlinger, Lisse: $311-314$.

Synowiec G., 2005. Formy i procesy osuwiskowe w Górach Kamiennych. Niepublikowana rozprawa doktorska. Instytut Geografii i Rozwoju Regionalnego, Uniwersytet Wrocławski.

Synowiec G., Migoń P., 2002. Rzeźba strukturalna Sudetów Środkowych. Przewodnik sesji terenowej B1, zorganizowanej w ramach VI Zjazdu Geomorfologów Polskich, Jelenia Góra Cieplice, 11-14 IX 2002. W: Przyroda Sudetów Zachodnich. Zeszyt Specjalny: 57-76.

Synowiec G., Traczyk A., 2004. Z morfologii Gór Kruczych w Sudetach Środkowych. Przyroda Sudetów 7: 191-204.

Szczepankiewicz S., 1954. Morfologia Sudetów Wałbrzyskich. Prace Wrocławskiego Towarzystwa Naukowego B65: 1-152.

Terhorst B., 2007. Periglacial cover beds and soils in landslide areas of SW-Germany. Catena 71: 467-476.

Terhorst B., Damm B., Peticzka R., Köttritsch E., 2009. Reconstruction of Quaternary landscape formation as a tool to understand present geomorphological processes in the eastern Prealps (Austria). Quaternary International 209: 66-78.

Thywissen K., 2006. Components of Risk. A Comparative Glossary. SOURCE, Publication Series of UNU-EHS 2: 1-48.

Timell T.E., 1986. Compression Wood in Gymnosperms. Springer, Verlag, New York.

Varnes D.J., 1978. Slope movement types and proceess. W: R.L. Schuster, R.J. Krizek (red.), Landslides: Analysis and Control. National Academy of Sciences, Washington DC: 11-33.

Vítek J., 1999. Geomorfologie Vraních hor. Práce a studie (Pardubice) 7: 3-20.

Walczak W., 1972. Sudety i Przedgórze Sudeckie. W: M. Klimaszewski (red.), Geomorfologia Polski. T. 1. PWN, Warszawa: 167-231.

Wistuba M., Malik I., Gärtner H., Kojs P., Owczarek P., 2013. Application of eccentric growth of trees as a tool for landslide analyses: The example of Picea abies Karst. in the Carpathian and Sudeten Mountains (Central Europe). Catena 111: 41-55.

Wistuba M., Malik I., Polowy M., Michałowicz P., w druku. Zastosowanie dekoncentryczności przyrostów rocznych w badaniach stoku o wysokim zagrożeniu osuwiskowym (Milówka, Beskid Żywiecki). Studia i Materiały Centrum Edukacji Przyrodniczo-Leśnej.

Wójcik J., 2011. Przemiany wybranych komponentów środowiska przyrodniczego rejonu wałbrzyskiego w latach 1975-2000, w warunkach antropopresji, ze szczególnym uwzględnieniem wpływu przemysłu. Rozprawy Naukowe Instytutu Geografii i Rozwoju Regionalnego, Uniwersytet Wrocławski, Wrocław.

Żurawek R., 1999. Zmiany erozyjne w dolinach rzek Sudetów Kłodzkich wywołane powodziami w lipcu 1997 r. oraz w lipcu 1998 r. Problemy Zagospodarowania Ziem Górskich 45: 43-61. 